\title{
COVID-19 acceleration in digitalisation, aggregate productivity growth and the functional income distribution
}

\author{
Björn Döhring ${ }^{1} \cdot$ Atanas Hristov $^{1} \cdot$ Christoph Maier $^{1} \cdot$ Werner Roeger $^{2,3}$. \\ Anna Thum-Thysen ${ }^{1}$
}

Accepted: 4 August 2021 / Published online: 25 September 2021

(c) The Author(s), under exclusive licence to Springer-Verlag GmbH Germany, part of Springer Nature 2021

\begin{abstract}
This paper characterises the conventional and the digital sector of the EU economy since the late 90 s and introduces a two sector growth model which highlights structural differences between the two sectors. In contrast to conventional goods and services, digital goods and services are more easily scalable but require more upfront intangible investment. These features require consideration of fixed costs and a departure from perfect competition and raise issues about market entry. Another important dimension is the skill demand of both sectors, with the latter requiring a larger share of workers with digital skills. Since COVID-19 is expected to induce a persistent increase of demand for digital services, we use this model to estimate the likely economic impacts. We are in particular interested how the digital transition is affecting the labour market and the functional distribution of income. The paper shows how the distribution of economic rents between workers with digital skills and platforms is determined by labour supply conditions and entry barriers. This suggests that there is a role for competition policy and labour market policies to support the digital transition.
\end{abstract}

Keywords Digital economy · Low marginal cost · Two-sector growth model · Technological change $\cdot$ Wage share

\footnotetext{
We are grateful to Anneleen Vandeplas and to our discussant Robert Kollmann for insightful comments and to participants of the EIIW-IEEP workshop: "How will COVID-19 affect an already fragile global economy?"for their comments and suggestions. We are also grateful to Wouter Simons for his contribution regarding the propagation of sectoral demand shocks. The views expressed in this paper are those of the authors and do not necessarily represent those of the European Commission.
}
Björn Döhring
bjoern.doehring@ec.europa.eu
1 European Commission, Brussels, Belgium
2 DIW Berlin, EIIW Uni Wuppertal, Berlin, Germany
3 VIVES KU Leuven, Leuven, Belgium 
JEL classification $\mathrm{O} 41 \cdot \mathrm{E} 10 \cdot \mathrm{J} 2$

\section{Introduction}

COVID-19 has accelerated the current wave of digital transformation. Following an earlier wave of communication technology and robotisation, the current wave is driven by further automation, communication technology, the internet of things, big data and artificial intelligence. These ongoing transformations can be expected to have a positive impact on productivity growth in the digital sector, but the effect is not necessarily visible at the aggregate level. If these are general-purpose technologies, the productivity impact would not remain confined to the digital sector. We partly take this into account by also looking at e-commerce in retail trade as a digital-adopting sector. Moreover, the digital transition may affect economic sectors and the workforce in quite differentiated ways, possibly exacerbating the decline in labour shares (functional income distribution) as well as modifying the demand for, and returns to, different types of skills.

In the corporate sector, firms that exploit digital platforms enabling them to expand activity at very low marginal cost are benefitting most from the COVIDrelated boost. Profits, sales and stock prices of major oligopolistic digital companies ("Big Tech" companies), which had already been so-called "superstar firms" with low labour shares before the pandemic (Autor et al. 2020), have risen sharply. ${ }^{1}$ Markups have also been rising pronouncedly in the digital sector characterized by fastpaced technological change (Calligaris et al. 2018) and oligopolistic competition.

In the labour market, low-wage earners in routine tasks have been hit hard by the pandemic. This broad group had already suffered from the impact of structural shifts and skills-biased technological change for many years. The boost to digitalisation is likely to lead to a reduction of the labour share, in particular if it is accompanied by a reduction of competition (Dierx et al. 2017) in the presence of network externalities. Furthermore, it is likely to shift the relative demand for skills in favour of highskilled workers.

This paper studies three questions, namely: (1) how will a shift of demand towards digital services affect aggregate productivity and output; (2) what are the possible effects on the functional income distribution, i.e. how are profits, wages and digital skill premia affected; and (3) what could be possible policy responses?

\footnotetext{
1 Combined, the four companies Google, Amazon, Facebook and Apple reach a market capitalisation value of nearly $\$ 5.5$ trillion in November 2020 entailing nearly $40 \%$ growth up from $\$ 4$ trillion in December 2019 and a 50\% growth on average since March 2020. Yahoo Finance; https://www.techchannel.news/11/11/2020/market-cap-of-big-five-tech-companies-surge-46-to-7-1tr-so-far-this-year/; https:// companiesmarketcap.com/tech/largest-tech-companies-by-market-cap/ and https:/www.vox.com/recode/ 2020/10/30/21541699/big-tech-google-facebook-amazon-apple-coronavirus-profits. Moreover, in the third quarter of 2020 they reported a quarterly net profit of \$38 billion (with Amazon's net profit growing $197 \%$ compared to the same time one year ago) Company reports; https://www.nytimes.com/2020/10/ 29/technology/apple-alphabet-facebook-amazon-google-earnings.html and https:/www.vox.com/recode/ 2020/10/30/21541699/big-tech-google-facebook-amazon-apple-coronavirus-profits
} 
We extend the standard one-sector neoclassical growth model by distinguishing a conventional and a digital sector. The latter is characterised by the presence of digital platforms with fixed costs but low marginal cost. In the model, entry of new platforms is endogenous and they are produced via an IT design production function with firms deciding about new varieties of digital goods. Workers are mobile between sectors and have digital or conventional skills, which are not substitutable. Physical capital is either of the information and communication technology (ICT) or the non-ICT type. We calibrate the conventional and the digital sector to EU data using information from EU KLEMS and Eurostat over the period 1997 to 2018. A positive demand shock in the digital sector simulates the surge in demand for digital services that occurred during the pandemic We explore the short and long run effects under the assumption that this demand shift is persistent. Our research question on the impact of such a demand shock on inequality echoes Stolper and Samuelson (1941) in their work on the rise or fall of inequalities given a rise in the relative price of a good.

An important policy response is the Next Generation EU instrument, which aims at accompanying the digital transition and supports the adaptation e.g. by fostering digital skills. Another possible policy scenario to explore could be the current revisions in the EU Digital Services Single Act set to "overhaul" the digital market, including how tech giants operate. We consider both the provision of digital skills and the effects of entry barriers in this paper.

\section{Literature Review}

\subsection{COVID and digitalisation}

Strong measures to contain the COVID-19 pandemic were first imposed in Asia in January 2020. By end-March 2020, stringent containment measures were in place around the globe. ${ }^{2}$ First, shutting down large parts of the physical economy provided a major boost to digitalisation, as social distancing has led to the increased use of digital channels, in particular e-commerce, digital entertainment, working from home, learning from home and digital public services (Claeys and Demertzis 2021; Priyono et al. 2020; Fletcher and Griffiths 2020; Nagel 2020, D’Adamo et al. 2021).

Second, by creating large uncertainty, COVID has also increased the value of timely and accurate data for business operations and decision-making (McKinsey 2020a; European Commission 2020). A third channel through which COVID speeds up digitalisation is by disrupting traditional business models e.g. for supply management and distribution (Rapaccini et al. 2020). A more general version of this argument relates to the 'QWERTY phenomenon' (David 1985). ${ }^{3}$ Suboptimal equilibria

\footnotetext{
${ }^{2}$ Cf. the COVID-19 Government Response Tracker by the Blavatnik School of Government https:// www.bsg.ox.ac.uk/research/research-projects/covid-19-government-response-tracker.

3 The QWERTY keyboard (and regional versions such as AZERTY or QWERTZ) minimises the risk of jamming typebars in mechanical typewriters. Although it is not the most efficient arrangement of keys for a digital typewriter or a computer keyboard the key configuration has persisted.
} 
can last long after the forces that led to them have vanished (path-dependency). A disruptive force such as COVID may facilitate the move towards a more globally effective equilibrium and the adoption of innovative technologies including digitalisation.

Fourth, Schumpeterian destruction triggered by COVID may increase the share of ICT-using firms in the economy. The use of digital technologies is related to higher productivity and profitability at firm level. More digitally advanced firms therefore have better chances to survive the recession and grow during the recovery. Van Ark et al. (2021) find preliminary evidence that ICT-intensive firms have generally experienced lower productivity losses during the pandemic. However, Furceri et al. (2021) warn that scarring effects in the aftermath of the deep recession caused by the pandemic might prevail, as sluggish reallocation of capital and labour would reduce TFP. Finally, boosting the digital transition is also among the objectives of the Next Generation EU programme. According to the rules for the National Recovery and Resilience Plans, EU Member States have to devote at least $20 \%$ of the funds they will receive to the digital transition. Additional public expenditure could for instance increase the availability of enabling digital technology such as broadband internet or 5G, and support the development of digital skills, both of which would allow firms to use the potential of more advanced digital solutions to the full extent.

As official statistics become available with a lag, the evidence on the impact of COVID on digital adoption is so far mostly derived from business surveys (European Investment Bank 2021; Fitzpatrick et al. 2020; Accenture 2020; Riom and Valero 2020). Strikingly, the EIB's Investment Survey suggest that firms that already have a high rate of digital adoption will continue to invest more than others in digital technologies in the coming years (European Investment Bank 2021). This could further increase the 'digital divide' between firms (Rückert et al. 2020).

\subsection{Digitalisation, productivity and profits}

Advances in ICT are generally expected to be productivity-enhancing, yet aggregate TFP growth has kept slowing down (Gordon 2016; Bloom et al. 2020; Claeys and Demertzis 2021). Explanations for this 'digital productivity puzzle' include (a) that ICT requires adaptation to production processes as well as particular skills and managerial capital. This may explain the growing productivity-divide between frontier firms and laggards (see e.g. Berlingieri et al. 2020; Andrews et al. 2018). Also, (b) being a general-purpose technology, ${ }^{4}$ a critical mass of ICT penetration may be required before aggregate productivity gains materialise. (Anderton et al. 2020; Brynjolfsson et al. 2019; Cardona et al. 2013). Van Ark et al. (2019) point to aboveaverage contributions to productivity growth from the most ICT-intensive industries.

A finding very relevant for our paper is that the concentration of activity in the most productive firms ('superstar firms') drives not only an increase in average

\footnotetext{
4 A general-purpose technology is characterized by 'pervasiveness' (a broad range of uses), 'improvement' (lowering costs in ICT producing and ICT using firms) and 'innovation spawning' (easier innovation in ICT producing and -using firms) (Cardina et al. 2013).
} 
productivity in the concerned sectors, but also a decrease in competition and higher mark-ups. (Autor et al. 2020; Calligaris et al. 2018). Economies of scale of intangible capital (such as low marginal costs of expanding platform services) and network externalities among users tend to strengthen the market power of the leading firms. These most productive and fastest-growing firms may however not systematically be the largest firms in terms of sales in a sector (Gutierrez and Philippon 2020).

The acceleration of digitalisation driven by COVID-19 could reinforce the observed concentration dynamics. Within the digital sector, this could lead to a decrease in the labour share (De Loecker et al. 2020; Dierx et al. 2017). At the same time, the increasing share of the digital sector (which has a below-average labour share) in the economy would also contribute to a decrease of the aggregate labour share. A declining labour share may not be the main driver of income inequality (Francese and Mulas-Granados 2015), but over longer periods, inequality in the functional income distribution does contribute to personal income inequality (Bengtsson and Waldenstöm 2018) and may thereby also cement wealth inequality (Piketty 2014).

\subsection{Digitalisation and skills demand}

It is well documented that technical progress has asymmetric effects on the demand for different sets of skills. From the initial view that the roll-out of ICT favours the demand for skilled workers at the expense of others ('skills-biased technical change', see e.g. Berman et al. 1998) the literature has moved towards favouring 'routine-biased technological change', which could lead to a polarisation of labour demand (e.g. Autor 2013) if medium-skilled workers are more likely to perform routine tasks.

Information and communication technology may act as substitute to low or mediumskilled labour, while acting as complement to high-skilled labour, thus affecting employment and wages of skills groups in a differentiated way (Consolo 2020). Grundke et al. (2018) assess the returns to skills (bundles of skills) and find that digital-intensive industries employ a higher share of highly skilled workers than less digital-intensive industries and that the same skills earn a higher reward in digital-intensive sectors. Michaels et al. (2014) find strong evidence that an increase of ICT use is related to an increase in the employment of high-skilled workers at the expense of demand for medium-skilled workers. Akerman et al. (2015) find that broadband internet access, which they interpret as enabling technology for other ICT applications, improves (worsens) the labour-market outcomes for skilled (unskilled workers). A moderating impact might arise in a context of international competition. If domestic firms invest in automation in order to better withstand foreign competition, domestic labour demand may increase across skills groups (Aghion et al. 2019).

Different manifestations of ICT may have different effects. Acemoglu and Restrepo (2017) find that industrial robots reduce employment, while other forms of ICT do not. Similarly, based on a survey of Swiss firms, Balsmeier and Woerter (2019) observe increases (decreases) in the demand for high-skilled (low-skilled) workers related to ICT. These effects largely stem from machine-based ICT such as robots, but not from e-commerce. 
High skills are an important asset but to reap the benefits of digital transformation, people need a broad set of skills (e.g. Morandini et al. 2020; Grundke et al. 2017). These include STEM skills - containing also ICT skills (Deming and Noray 2018) - but also wider set of skills including entrepreneurship, critical thinking, creativity, flexibility and interpersonal skills such as collaboration and communication (Autor 2015) to carry out non-routine tasks.

In this paper, we focus on a narrower set of advanced digital skills such as programming. We use the "ICT professionals" ISCO category to proxy what we refer to in the following as "digital skills".

Regarding COVID-19, first evidence suggests that it has reinforced the pre-crisis trend of structural change that increases the demand for high-skilled workers at the expense of demand for relatively low-skill occupational and education groups (Mattana et al. 2020; Croitorov et al. 2021). The direct impact of COVID and related lockdowns and partial functioning of the economy is likely to have increased the risk of inequality and poverty (Palomino et al. (2020), but support measures have dampened that impact (Almeida et al. 2020).

\subsection{A closer look at productivity and skills demand in retail ${ }^{5}$ e-commerce}

2020 has seen a surge in the use of B2C e-commerce, and at least some of the shift of retail sales online is expected to last after COVID (OECD 2020).

The literature finds e-commerce to increase firm productivity. The empirical analysis generally covers several sectors at once, more often in manufacturing than in services. As we are not aware of studies that zoom in on productivity specifically in electronic versus offline retail commerce, we review the literature about productivity in e-commerce in general. Indeed, most studies proxy 'e-commerce' as the share of firms engaged in some form of e-commerce or, when using firm-level data, use a dummy variable for firms that practice e-commerce. An example of a study using the intensity of e-commerce transactions at the firm level is Liu et al. (2013).

Falk and Hagsten (2015) analyse sectorally aggregated firm-level data for 14 European countries (ESSLait Micro Moments Database). They find that an increase in the share of firms with e-sales activities of one percentage point leads to an increase in the rate of labour productivity growth by 0.12 percentage points over a two-year period. The productivity impact tends to be more substantial for SMEs than for large companies. Konings and Roodhooft (2002) examine a sample of Belgian firms in manufacturing and services and find that those engaging in on-line selling have a $15 \%$ higher total factor productivity then those that do not. Quiroz Romero and Rodríguez Rodríguez (2009) find that for manufacturing firms in Spain, e-buying increases productivity, but e-selling does not. Liu et al. (2013) look at

\footnotetext{
5 E-commerce is the sale or purchase of goods or services via computer networks using methodologies designed for placing and receiving orders (OECD definition).). It can have different dimensions: Business-to-business (B2B) continues to dominate e-commerce turnover, while e-commerce is also present in public procurement (business-to-government B2G), increasingly in retail trade (B2C) and transactions between individuals (OECD 2019). We focus here on the retail (B2C) dimension.
} 
manufacturing firms in Taiwan and find that e-commerce (measured by transactions) and R\&D are complementary in increasing firm productivity. The impact of e-commerce on its own is statistically significant but quite small.

There are few studies that deal with the labour-market effects of e-commerce. At the firm level, the impact of product and process innovation associated with internetuse on employment is found to be positive (Koellinger 2008). At the level of sectors (meso-level database by Bartelsman) adopting e-commerce may however not have a significantly positive employment impact (Biagi and Falk 2017). E-commerce is however found to have a negative impact on employment in offline retail (Chava et al. 2018; Cardona et al. 2015). ${ }^{6}$

Concerning the impact of e-commerce on workers with different skill sets, several papers conjecture that skills-biased technical change applies to e-commerce in a similar way as to ICT in general (Terzi 2011; UN ECLAC 2002; OECD 1999).

In (B2C) e-commerce, the display of products, product advice, their selection by the customer and payment are moved to a digital platform. Physical product delivery takes place directly from a warehouse to the consumer, cutting out bricks-and-mortar shops. We would therefore expect the loss of mostly low-skilled jobs in physical shops (and a few medium-skilled jobs of qualified shop assistants in specialised retail shops). Efficiency gains from consolidating logistics would imply that fewer jobs are created in warehousing and delivery services than the jobs lost in offline shops. High-skilled jobs would be created in digital services (and a few in logistics).

\subsection{Modelling COVID as an accelerator of the digital transition}

The current wave of digitalisation is not a consequence of COVID, but COVID has an accelerating effect, leading to a boost in ICT adoption. Official statistics on the turnover of the IT industry in 2020 are not yet available, but trends seem to have differed a lot across sub-sectors. ICT investment ${ }^{7}$ appears to have dropped in 2020, but far less than capital formation overall. Subsectors such as videoconferencing, cloud computing or e-commerce have boomed. Moreover, ICT investment is expected to expand particularly strongly in the aftermath of the pandemic.

COVID containment measures have boosted e-commerce (e.g. OECD 2020), , notably with respect to retail sales (covering a wide range from print media over furniture and IT equipment to clothing and groceries) and digital entertainment (movies, music). The turnover of Amazon and similar platforms has increased by close to $40 \%$ in 2020 . In the US, the total volume of online sales increased $44 \%$ in the second quarter of 2020 compared to the same quarter a year earlier, as its share in retail commerce increased from $10.5 \%$ to $15.7 \% .^{8}$ In tourism and accommodation, the e-commerce share was already rather high before the crisis. Tourism activity has fallen sharply due to pandemic containment measures. However, it is likely to rebound as restrictions are lifted. There may be permanent shifts in travel

\footnotetext{
${ }^{6}$ Cardona et al. also perform simulations on the aggregate macroeconomic impact of e-commerce and find that it has an overall positive impact on GDP.

7 As measured in national accounts, which excludes e.g. household spending on ICT.

8 The Department of Commerce's quarterly e-commerce statistics are available from https://www.census.gov/retail/index.html.
} 
destinations and modes (cf. Borko et al. 2020), but this is unlikely to affect the overall volume of internet bookings in the longer run. Business travel is more likely to suffer a permanent and considerable shock affecting several sectors like air transport and accommodation and food services around government and industrial centres. A reasonable scenario could be a permanent COVID-induced boost of e-commerce sales volumes in the order of $20 \%$. This leads to a less-than-proportional increase in the demand for related digital equipment and services (low marginal cost of expanding activity over platforms).

Another booming 'sector' with implications for ICT investment is working-fromhome. Around $37 \%$ of jobs in the EU can be performed from home (Sostero et al. 2020). Part of the COVID-related increase in working from home is also likely to be permanent, as companies and workers have now experienced the benefits. To a smaller extent, some share of 'learning from home' may remain permanent for tertiary education, as following online courses has become more common and the offer is very attractive. Recent surveys for the US suggest that the average employee whose job is suitable for telework would like to work from home 2-3 days per week after the pandemic, and that their employers foresee 2 teleworking days per staff per week. Applied to the EU, that would represent $15 \%$ of employees working from home on any given working day, up from a very small fraction of workers (Barrero et al. 2021; Nagel 2020). Working from home does not involve professional digital skills (and we will exclude it from our definition of the digital sector, but it boosts demand for digital equipment and services. As workers will not take all office equipment on the commute between the home and the office, there will be a permanent increase in the stock of office equipment (in particular standard peripherals such as screens, printers, keyboards etc.). Increased demand for digital services includes subscriptions to internet, videoconferencing services and cloud computing. A reasonable scenario for the permanent impact of working from home (see detailed explanations in Annex 2) could be a $15 \%$ increase of demand for digital services and somewhat less for office equipment.

To these salient examples, one needs to add the increase of ICT demand stemming from firms' efforts to speed up the use of AI and big data and to increase productivity in general in order to survive the disruption and the shake-out provoked by the crisis.

The data collected by business consultancies and business surveys suggest that ICT activity in 2020 has expanded by about 3-5 times the rate of growth expected in a normal pre-pandemic year (McKinsey 2020a). Given the positive impact on firms' competitiveness as well as the policy support for the digital transition, it is reasonable to assume that a part of this boost to activity is permanent. We therefore assume a permanent boost to the volume of ICT activity by $10-15 \%$ (with $10 \%$ representing about 2-3 years of 'normal' annual growth) as starting point for the simulations. Note that for activity to remain on a permanently higher path than it would have been without the pandemic, it is sufficient that the particularly fast growth in 2020 is not fully compensated by lower growth in subsequent years.

A first approximation of how such an ICT demand shock may spread beyond the digital sector can be derived from input-output analysis. The (upstream) propagation of a demand shock to digital services is fairly limited. Using the OECD input-output 
database a $10 \%$ demand shock to sector $\mathrm{J}$ (Information and Communication) leads to an increase of value added of less than $1 \%$ in other sectors (Fig. 1).

The most strongly impacted sectors (upstream) are paper and print (C17 to C18), professional and administrative services (MTN) and the manufacturing of IT equipment (C26).

The shift to working from home and e-commerce could however have additional indirect effects on the construction and transport sectors that are not picked up by input-output analysis. Working from home and de-urbanisation may negatively affect productivity growth as agglomeration effects are reduced (see literature review in Combes and Gobillon 2014; also Gornig and Schiersch 2019; Brunow and Blien 2015). On the other hand, it has been documented that time saved commuting is in part reallocated to working longer hours (Barrero et al. 2021).

The increase of e-commerce and working from home are set to reduce the demand for commercial and office space in cities. The impact on the construction sector is negative and potentially large (see Annex 2). Videoconferencing is likely to replace a part of business travel with negative repercussions in particular on airlines and rail (cf. Borko et al. 2020). With more widespread working from home, commuting would become less frequent, but distances may increase as living outside urban centres becomes more attractive. In this case, reduced population density favours individual transport solutions over public transport. Finally, e-commerce increases the demand for delivery services, but decreases individual traffic to physical shops (McKinsey 2020a).

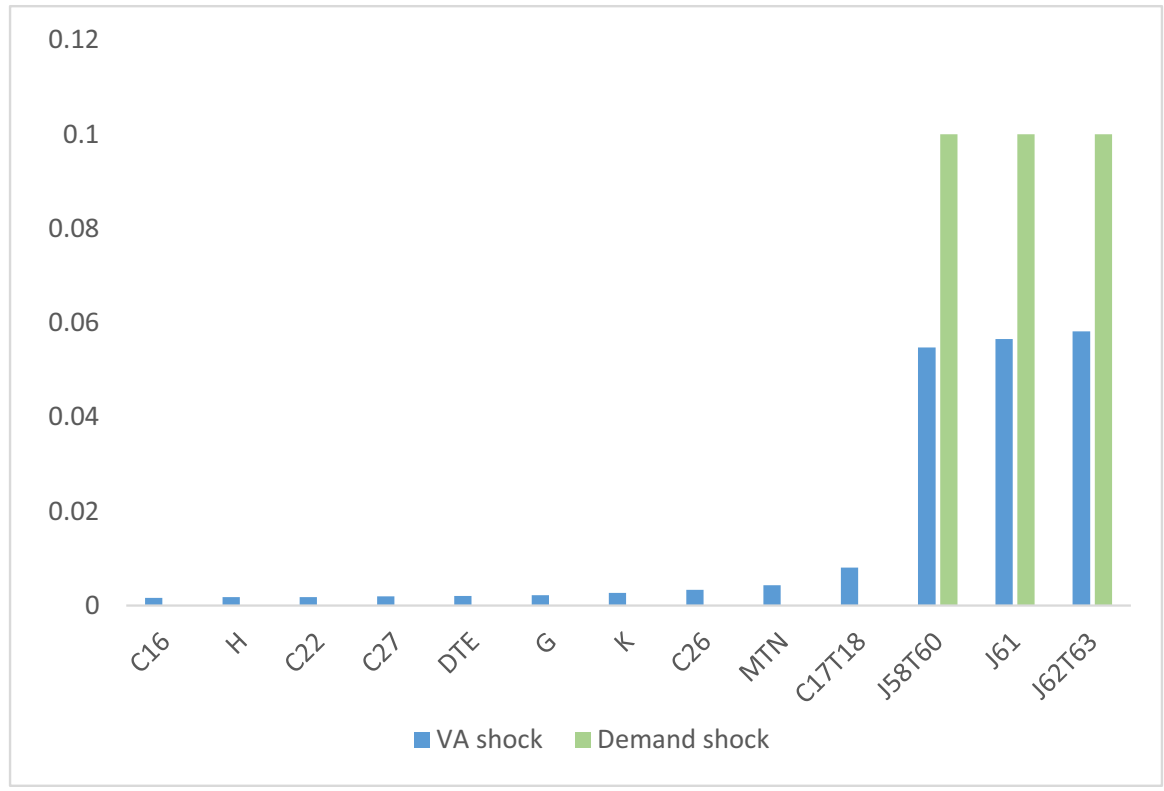

Fig. 1 Propagation of $+10 \%$ demand shock to sector J (Information and Communication), EU. Source: OECD, own calculations. 


\section{Stylised facts}

Economic activities related to digitalisation are spread over various NACE sectors. For the purpose of our modelling exercise, we want to distinguish a 'digital sector' that is characterised by a high concentration of workers with professional digital skills, and by the presence of low marginal costs. These appear to us as key features of the current wave of digitalisation. We therefore define the digital sector as NACE section J ("Information and Communication") plus e-commerce (captured by NACE section 47.91 "Retail sale via mail order houses or via Internet"), which is one of the most dynamic parts of the digital economy, and we define the rest of the economy as 'conventional'. Some definitions by others (see Benages et al. 2020) include also subsectors of a manufacturing sector covering "Computer, electronic and optical products" (sectors 26.1-26.4) and "Computer repair services" (sector 95.1). Also the spread of the use of industrial robots could be considered a manifestation of digitalisation in manufacturing (see, e.g. Acemoglu and Restrepo 2017). However, in this paper we are mostly interested in the specific features of digital platforms, and therefore leave aside the developments proper to manufacturing (in general and manufacturing of computer hardware).

The share of the digital sector in total value added of the market economy in the EU was 6.8\% (sector J) and 7\% (sector J plus 47.91) in 2017 (see Fig. 2). This is lower than in the US, where sector J accounted for slightly more than $10.8 \%$ at that time, or $11.7 \%$ in the broader definition including e-commerce. We use the EUKLEMS database for most series as well as the EU Labour Force Survey and the Structured Earnings Survey and provide calculations for the EU27 aggregate. ${ }^{9}$ The JRC PREDICT dataset (Benages et al. 2020) is also used to complement the picture.ss

In the years 2000-2017, activity in the 'nasrrow' digital sector in the EU has grown by $4 \%$ annual average against $1 \%$ for aggregate output (see Fig. 3). Firms from the digital sector dominate the international league tables for R\&D investment (EIB 2021). The intensity of digital adoption is positively related with good management practices, TFP and employment growth (EIBIS, 2020).

The labour and capital inputs in the digital sector are quite distinct from the rest of the market economy. Firstly, the digital sector uses a much higher share of intangible capital (defined here as R\&D and software and databases) than the other sectors, and the share is increasing fast, representing almost $50 \%$ of the sectors' overall capital in 2017 (see Fig. 4).

Secondly, staff with specialised IT skills (defined as ICT professionals in the ISCO classification) represent about $41 \%$ of employment in the digital sector against just $4 \%$ of employment in the rest of the market economy in 2020. Such digital skills earn a premium: The wages of digital professionals were on average $7.6 \%$ higher than those of other professionals in 2018 (Structured Earning Survey) (Fig. 5).

Labour productivity in the digital sector is higher than in the rest of the market economy, and has been increasing faster both in the EU and the US (see Fig. 6).

\footnotetext{
9 The period 1995-2017 is the maximal range and some series are shorter or contain fewerfewer countries in the EU aggregate. The employment share of digital skills is available for the period 2010-2020 and the wage premium for digital skills is available for 2008, 2010 and 2014.
} 
Fig. 2 Value added share of the digital economy. Source: EUKLEMS.S

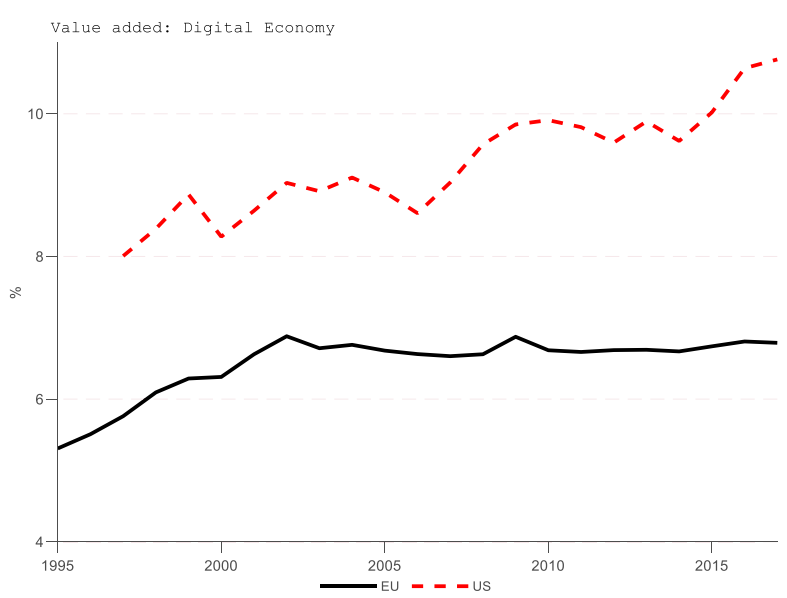

However, compared to the US, labour productivity growth has been slow. A possible explanation could be the nature of the activities of subsidiaries of UD digital platforms in the EU, which are more engaged in applied activities while the mother companies in the US concentrate innovative activities.

In the digital sector in the EU, the wage share is lower, at $57 \%$ than in the rest of the market economy (67\% in 2017, see Fig. 7). In the US, the difference is more pronounced. Interestingly, the wage share, both in the digital sector and the rest of the market economy has been on a declining trend in the US over the past two decades, whereas in Europe, the wage share has been more stable overall, and on a slightly increasing trend in the digital sector. At the same time, the concentration of professional ICT skills in the digital sector has increased. The share of workers with advanced digital skills has been rising in the EU's digital sector from 30 to $40 \%$ between 2010 and 2020 .

Fig. 3 Gross value added in the digital sector versus the market economy (growth rates). Source: EUKLEMS.

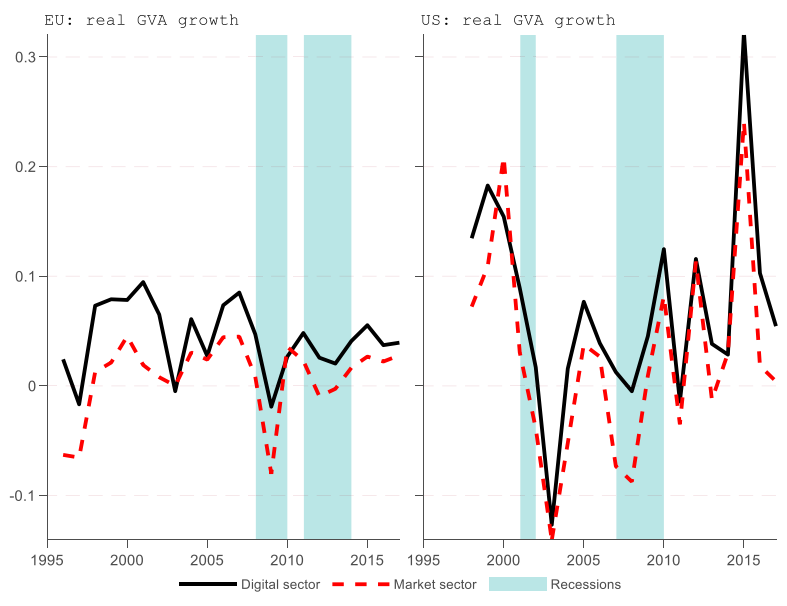


Fig. 4 Investment share of intangible assets. Source: EUKLEMS.

Fig. 5 Employment shares of digital professionalsl in the digital sector and in the market economy. Source: EU Labour Force Survey

Fig. 6 Labour productivity. Source: EUKLEMS.
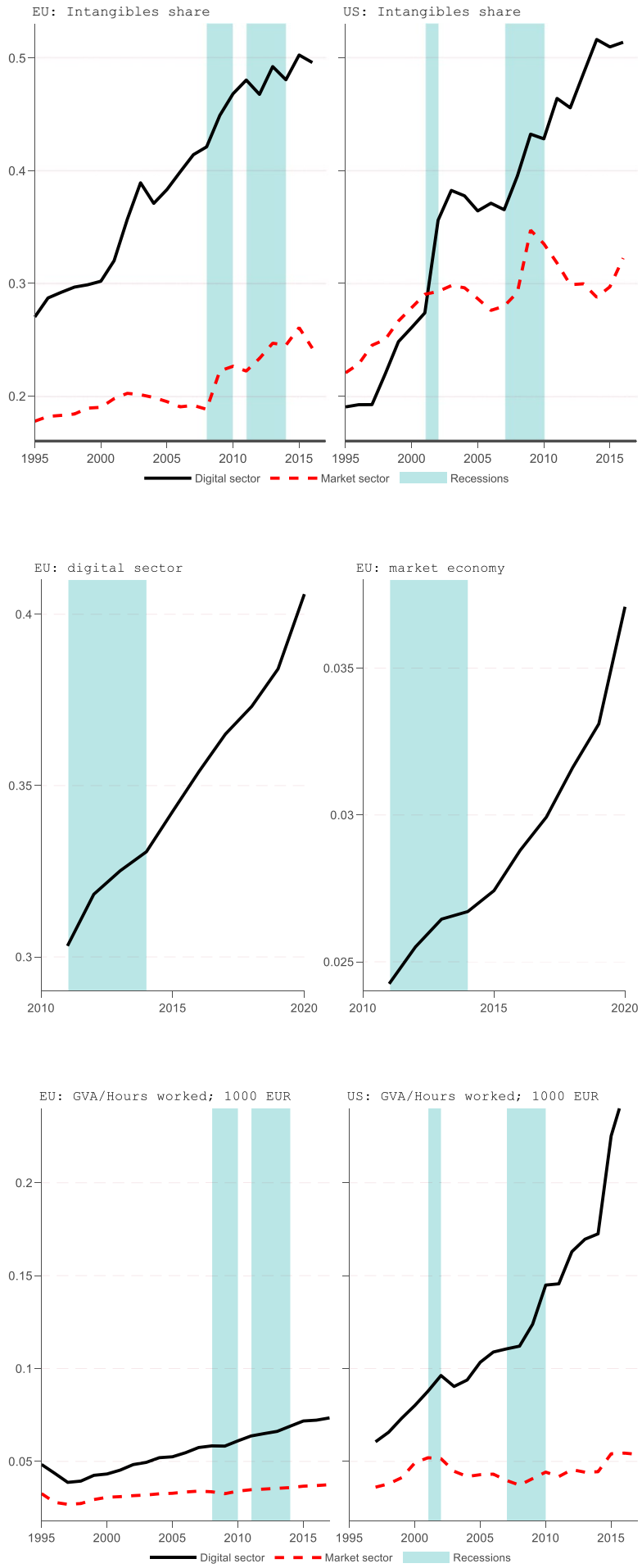
Fig. 7 Wage share. Source: EUKLEMS

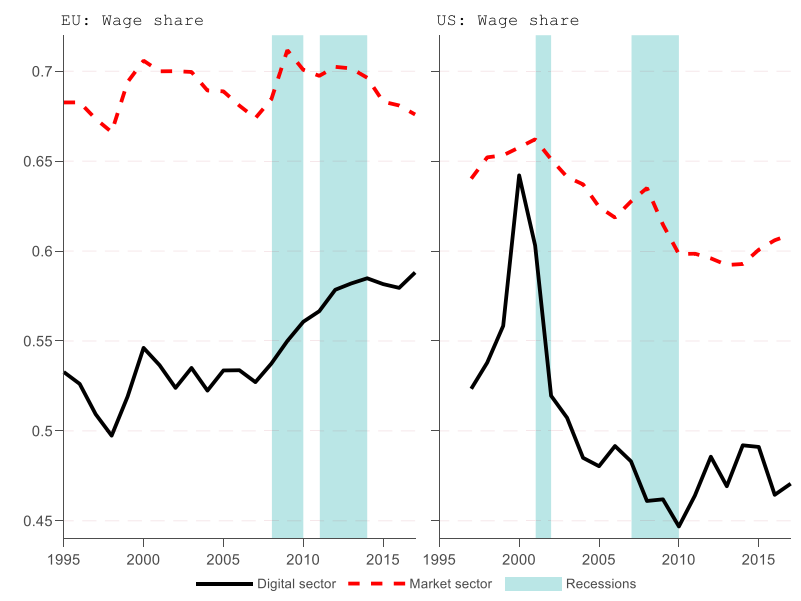

In the EU, profit shares have been higher in the digital sector compared to the non-digital sector until around 2013 and the sample average (1995-2017) is at 9\% for the digital sector versus $4 \%$ for the non-digital sector in the EU27. Profit shares are declining in the EU since the late 2010s. A factor contributing to this could be that profits are not always reported in a transparent way due to tax optimisation practices. Ireland might have attracted reported profits due to the lower corporate tax regime in place, but Ireland is not included in our sample due to missing data. In the US, the profit rate in the digital sector was in negative territory in the 1990s and 2000s and caught up with the non-digital sector only towards the end of the 2010s. Profit shares in value added are based on profits defined as value added net of the wage bill and capital services. Capital costs are based on the Hall-Jorgensonian (1967) formula, where adjustments are made for corporate taxes and depreciation allowances and for cost of borrowing (based on the long-term interest rate).

Prices (as measured by the GVA deflator) decline in the digital sector as opposed to prices in the non-digital sector. The digital sector is benefitting more from price declines in ICT, software and R\&D capital, which it uses more intensely than the non-digital sector does (Figs. 8 and 9)

\section{The model}

\subsection{Model description}

Autor and Salomons (2018) stress the necessity to look at the labour-market impacts of digitalisation in a general-equilibrium setting. There is some literature that characterises firms operating in the digital sector as firms with low or even zero marginal cost (see e. g. Rifkin, Dhar and Sundararajan 2007; Sundararajan 2016). Waldfogel (2015) documents that in the recorded music industry, 
Fig. 8 Profit shares, digital and non-digital sector. Source: EUKLEMS
Fig. 9 Relative prices - GVA deflators, digital and non-digital sector. Source: EUKLEMS
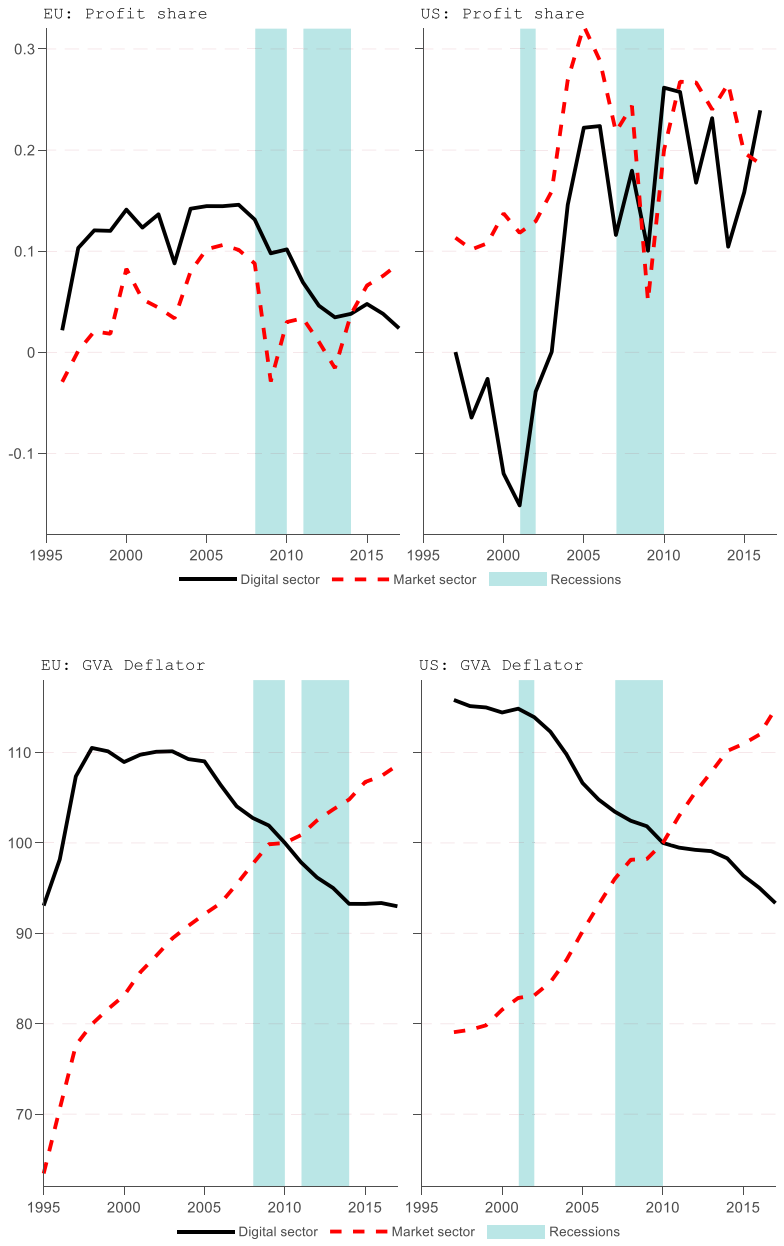

digitalisation lowered marginal distribution costs and increased product variety. Berry et al. (2019) point out that industrial organisation studies also suggest that large firms are in fact changing products and production methods, including the mix of marginal and fixed costs, over time. The industry studies seem to suggest that "fixed costs' are often actually sunk costs that are built up through time via investments in networks, product quality, geographic location, and so forth. Bessen (2017) provides evidence that customised software-used routinely by large corporations today - requires large up-front fixed sunk costs. Korinek and $\mathrm{Ng}$ (2017) make an attempt to introduce firms with high fixed cost and zero marginal cost into an otherwise standard growth model. Here we emphasise the intangible capital requirement of digital platform production, which we essentially model as a sunk cost for the firm before entering the digital sector. To model entry with a digital design we borrow from the literature on endogenous growth (see Romer 1990 or Grossman and Helpman 1992a). Thus our model differs from the 
standard neoclassical growth model in various dimensions. First, the economy consists of a conventional goods sector and a digital sector. The conventional goods sector is characterised by a standard production technology where output is produced with a Cobb Douglas production function with constant returns to scale and there are no fixed costs. In the digital sector platforms offer services at low marginal cost but they face a sunk cost for the design which is a prerequisite for opening a platform. In addition they face fixed cost in each period, due to the IT hard ware requirements for operating the platform. Complementarity between hardware and IT staff makes a fraction of workers also overhead for the platform. Marginal cost for the platform are small because changing the supply of digital services only requires a small change in the staff. The design for opening a platform can be obtained from a perfectly competitive software producer that generates designs using a linear technology. The IT hardware is supplied by a sub sector of the conventional production sector that transforms the conventional good into an IT capital good using a linear technology. A second difference with the standard growth model concerns the labour market. Households supply labour with and without (professional) digital skills and the two sectors demand these two types of labour in fixed (but sector specific) proportion. Labour supply is skill-specific but not sector-specific, i. e. workers with and without digital skills are fully mobile across sectors. Education and training are not explicit in our model. To increase the supply of a specific skill, in our model workers need to move from inactivity to employment.

\subsubsection{Household}

Households rent capital $K_{t}^{O}$ to the conventional production sector and IT capital $K_{t}^{I T}$ to the platform sector. The household invests into $A_{t}$ platform designs that are a prerequisite for platform production. Arbitrage conditions require that expected returns from these three types of investment are equalised There are no adjustment costs for physical capital, but there is an entry costs for new platforms $\left(\theta A_{t}^{v} \Delta A_{t}\right)$. which is a convex function $(v>1)$ of the number of platforms. The household maximises an intertemporal utility function over consumption and two types of labour with and without digital skills $\left(L_{t}^{H}, L_{t}^{L}\right)$ subject to an intertemporal budget constraint.

$$
\begin{aligned}
& \mathcal{L}=\sum_{t=0}^{\infty} \beta^{t} U\left(C_{t}, L_{t}^{L}, L_{t}^{H}\right)-\sum_{t=0}^{\infty} \beta^{t} \lambda_{t}\left(B_{t}^{N}+\int_{0}^{A_{t}} P_{j t}^{A} d j-\left(1+i_{t-1}\right) B_{t-1}^{N}-\right. \\
& r_{t-1}^{K^{O}} P_{t}^{Y} K_{t-1}^{O}+P_{t}^{Y}\left(K_{t}^{O}-\left(1-\delta^{O}\right) K_{t-1}^{O}\right)+P_{t}^{Y} \quad C_{t}+\int_{0}^{A_{t}} P_{j t}^{x} x_{j t} d j+\theta A_{t}^{v} \Delta A_{t}-W_{t}^{L}\left(L_{t}^{O, L}+\right. \\
& \left.A_{t} L_{t}^{D, L}+L_{t}^{A, L}\right)-W_{t}^{H}\left(L_{t}^{O, H}+A_{t} L_{t}^{D, H}+L_{t}^{A, H}\right)-\int_{0}^{A_{t}} \pi_{j t} d j-\int_{0}^{A_{t-1}} P_{j t}^{A} d j-r_{t-1}^{K^{I T}} P_{t}^{I T} K_{t-1}^{I T}+ \\
& \left.P_{t}^{I T}\left(K_{t}^{I T}-\left(1-\delta^{I T}\right) K_{t-1}^{I T}\right)\right)
\end{aligned}
$$

The utility function is additively separable in $C_{t}, L_{t}^{L}$ and $L_{t}^{H}$

$$
U\left(C_{t}, L_{t}^{L}, L_{t}^{H}\right)-\log \left(C_{t}\right)-\omega^{L} L_{t}^{L^{1+\varphi}}-\omega^{H} L_{t}^{H^{1+\varphi}}
$$


Households have CES preferences for a conventional good $C_{t}^{O}$ and an aggregate of digital services $C_{t}^{D}$ with elasticity of substitution $\sigma$.

$$
C_{t}=\left[\gamma_{t}^{\frac{1}{\sigma}} C_{t}^{O \frac{\sigma-1}{\sigma}}+\left(1-\gamma_{t}\right)^{\frac{1}{\sigma}} C_{t}^{D^{\frac{\sigma-1}{\sigma}}}\right]^{\frac{\sigma}{\sigma-1}}
$$

Their preferences for digital varieties can also be expressed by a CES utility function with elasticity of substitution between varieties equal to $\theta$.

$$
C_{t}^{D}=\left[\int_{i=0}^{A_{t}} C_{i t}^{D \frac{\theta-1}{\theta}} d i\right]^{\frac{\theta}{\theta-1}}
$$

Incumbent firms decide about the supply of variety $i$. The number of varieties of digital services $A_{t}$ is not fixed but determined by investment decisions to create platforms in the digital sector. These preferences imply the following demand functions

$$
C_{t}^{O}=\gamma_{t}\left(\frac{P_{t}^{O}}{P_{t}}\right)^{-\sigma} C_{t}
$$

and

$$
C_{t}^{D}=\left(1-\gamma_{t}\right)\left(\frac{P_{t}^{D}}{P_{t}}\right)^{-\sigma} C_{t}
$$

Demand for digital varieties can be further disaggregated

$$
C_{i t}^{D}=\left(\frac{P_{i t}^{D}}{P_{t}^{D}}\right)^{-\theta} C_{t}^{D}
$$

Increased demand for digital services will be captured by an increase of the share parameter $1-\gamma_{t}$ of digital goods, which leads to an upward shift in the demand for the digital aggregate and a downward shift for the demand of conventional goods.

\subsubsection{Conventional goods sector}

We assume that the physical good is produced under perfect competition, with firms using a CRS production technology.

$$
Y_{t}^{O}=u_{t}^{O} L_{t}^{O^{\alpha}} K_{t}^{1-\alpha}
$$

Where $u^{O}$ is an efficiency parameter, $K$ is physical capital and $L^{O}$ is a composite labour input given by a Leontief aggregator. 


$$
\begin{gathered}
L_{t}^{O}=\min \left(\frac{1}{s^{O L}} L_{t}^{O L}, \frac{1}{s^{O H}} L_{t}^{O H}\right), \quad s^{O L}+s^{O H}=1 \\
\min \left(\frac{1}{s^{O L}} L_{t}^{O L}, \frac{1}{s^{O H}} L_{t}^{O H}\right)
\end{gathered}
$$

Where $L_{t}^{O H}$ and $L_{t}^{O L}$ is labour input of workers with and without digital skills respectively. The Leontief specification implies that a fixed fraction $s^{O H}, s^{O L}$ of workers with and without professional digital skills are employed in the conventional production sector. We assume the skill structure to be non-digital intensive, i. e the share of workers with digital skills is small.

$$
s^{O L}>s^{O H}
$$

The Leontief assumption reflects the fact that digital technologies require specialised skills and there is little possibility to replace a worker with digital skills by a worker without digital skills. Firms minimise cost and take wages and the rental price of capital as given.

IT Hardware Production A subsector of the physical production sector produces IT hardware. Here we assume that perfectly competitive IT hardware producers use goods produced by the physical production sector as input $\left(I_{t}^{I T O}\right)$ and transform them into IT equipment $\left(I_{t}^{I T}\right)$. Production of IT equipment is subject to a technology $\operatorname{shock} u_{t}^{I T}$.

$$
I_{t}^{I T}=I_{t}^{I T O}\left(1+u_{t}^{I T}\right)
$$

Because of perfect competition the price of computer equipment is given by

$$
P_{t}^{I T}=\frac{P_{t}^{O}}{1+u_{t}^{I T}}
$$

\subsubsection{Digital sector}

The platform operates with high fixed costs and small marginal cost. We model fixed input requirement $F I_{i t}^{D}$ of platform $i$ as a Leontief technology which combines IT hardware with labour in fixed proportions

$$
F I_{i t}^{D}=\min \left(\frac{1}{1-s^{D, K}} L_{i t}^{D, F}, \frac{1}{s^{D K}} K_{i t}^{D K}\right)
$$

The platform uses labour with and without digital skills in fixed proportions. For changing the scale of operation the platform needs to change variable labour input. For simplicity we assume that the platform uses labour with and without digital skills in the same proportion in both aggregates 


$$
L_{i t}^{D, j}=\min \left(\frac{1}{s^{D, L}} L_{i t}^{D, L, j}, \frac{1}{s^{D, H}} L_{i t}^{D, H, j}\right) \quad j=F, V
$$

And that production in the digital sector is digital-skill intensive

$$
s^{D, H}>s^{D, L}
$$

Output of platform i $Y_{i t}^{D}$ is proportional to the variable labor aggregate $L_{i t}^{D, V}$

$$
Y_{i t}^{D}=L_{i t}^{D, V}
$$

Thus, the operating cost each period of the platform can be divided into variable and fixed costs. Variable costs are given by

$$
C^{V}\left(W_{t}^{H}, W_{t}^{L}, Y_{i t}^{D}\right)=\left(s^{D, H} W_{t}^{H}+s^{D, L} W_{t}^{L}\right) Y_{i t}^{D}
$$

And fixed cost for each platform are given by

$$
C^{F}\left(W_{t}^{D}, r_{t}^{K, D}, L_{i t}^{D, F}, K_{i t}^{D K}\right)=\left(1-s^{D, K}\right)\left(s^{D, H} W_{t}^{H}+s^{D, L} W_{t}^{L}\right) L_{i t}^{D, F}+s^{D, K} r_{t}^{K, D} K_{i t}^{D K}
$$

Variable costs are proportional to output per platform $Y_{i t}^{D}$ while fixed costs are proportional to the number of platforms $A_{t}$. Since varieties produced by platforms are imperfect substitutes, they engage in monopolistic competition and face a demand function as represented by Eq. 6. The period profit of the platform is given by

$$
\pi_{i t}=P_{i t}^{D} Y_{i t}^{D}-C^{V}\left(W_{t}^{D}, Y_{i t}^{D}\right)-C^{F}\left(W_{t}^{D}, r_{t}^{K, D}, L_{i t}^{D, F}, K_{i t}^{D K}\right)
$$

Where $C^{j}(),. j=V, F$ is the Leontief variable and fixed cost function. Entry of platforms takes place until the present discounted value of profits of the marginal platform is equal to the design price for the platform plus marginal entry cost. We assume that entry costs are convex, i. e. it becomes more difficult to overcome network externalities as the number of platforms gets larger

$$
P_{t}^{A}+\left(v \theta A_{t}^{v-1} \Delta A_{t}+\theta A_{t}^{v}\right)=\pi_{t}+\frac{\beta \lambda_{t+1}}{\lambda_{t}}\left(P_{t+1}^{A}-\left(\nu \theta A_{t+1}^{v-1} \Delta A_{t+1}-\theta A_{t+1}^{v}\right)\right)\left(P_{t+1}^{A}-\left(v \theta A_{t+1}^{v-1} \Delta A_{t+1}-\theta A_{t+1}^{v}\right)\right)
$$

The arbitrage condition of the household implies that the household is willing to invest in new platforms until the price of the design plus marginal entry cost is equal to the platform profit plus the (discounted) price of the design adjusted for the foregone entry cost in the next period.

Designs, which are a prerequisite for platform production are created by a platform design sector. Here, we follow the endogenous growth literature ${ }^{10}$ (see Romer (1990) or Grossman and Helpman (1992b)) and assume that there are perfectly competitive (software) firms which produce designs for new digital varieties using a linear production function using digitally skilled labour $L_{t}^{A, H}$

\footnotetext{
${ }^{10}$ Because the knowledge production function is linear in labour input our model does not generate endogenous growth.
} 


$$
\Delta A_{t}=u_{t}^{A} L_{t}^{A, H}
$$

with efficiency parameter $u_{i t}^{A}$. The price for a new design is therefore given by

$$
P_{t}^{A}=\frac{W_{t}^{H}}{u_{t}^{A}}
$$

\subsubsection{Equilibrium conditions}

There is an equilibrium condition for labour of type $\mathrm{L}$ and type $\mathrm{H}$

$$
\begin{gathered}
L_{t}^{L}=A^{O} L_{t}^{O L}+A_{t}^{D} L_{t}^{D L} \\
L_{t}^{H}=A^{O} L_{t}^{O H}+A_{t}^{D} L_{t}^{D H}+L_{t}^{A H}
\end{gathered}
$$

Goods market equilibrium for final good

$$
\begin{gathered}
Y_{t}^{O}=C_{t}^{O}+I_{t}^{O}+I_{t}^{I T O} \\
Y_{t}^{D}=C_{t}^{D}
\end{gathered}
$$

\subsection{Calibration}

Following closely the OECD convention we define the digital sector to be comprised of NACE industries J58 (publishing activities: books, periodicals, audio books, electronic periodicals), J59 (motion pictures, video and television, sound recording and music publishing activities), J60 (programming and broadcasting), J61 (telecommunications), J62 (computer programming, consultancy and related activities), J63 (information service activities) - defined as the 'narrow digital sector' (see also Section 3). We also look more closely at a 'broader digital sector' including e-commerce regarding the value added share. We use data from EU KLEMS to calibrate the preference and technology parameters in the model. We select the preference parameters such that the model replicates a nominal sector share of $7 \%$ in the digital sector (Table 1).

Given the rough constancy of the digital share since 2000, we assume an elasticity of substitution equal to one between conventional and digital goods for most of the analysis. The calibration of technology in the conventional sector is standard. We assume a Cobb Douglas production function with output elasticity of labour and capital equal to 0.65 and 0.35 respectively, roughly consistent with the observed average wage share in the non-digital sector. We do not distinguish between tangible and intangible capital and we do not distinguish between ICT and non-ICT tangible capital (software and R\&D) in the conventional production sector. For the digital 


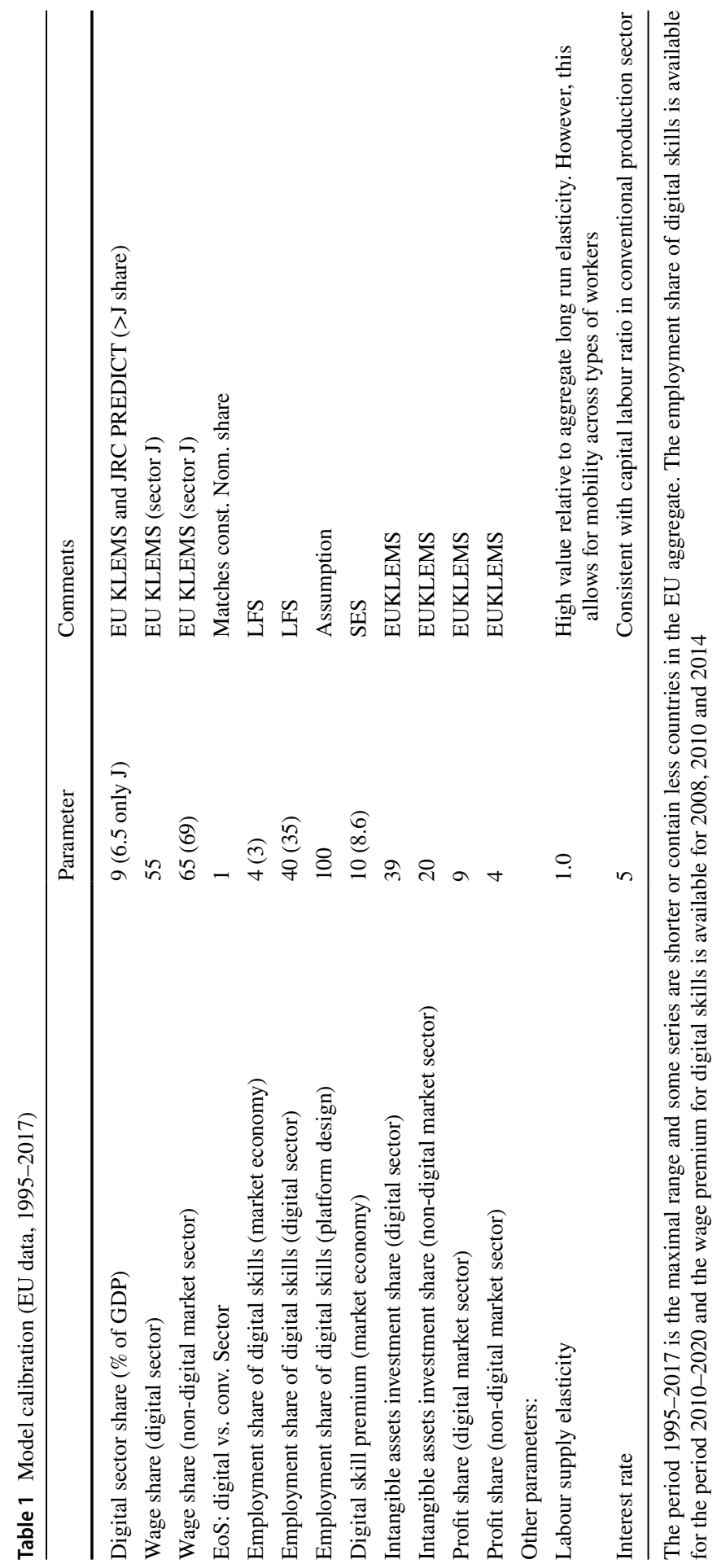


sector, the production parameters are set such that the model replicates a wage share of $55 \%$ and a profit share that exceeds the profit share in the conventional production sector by $5 \mathrm{pp}$. over the sample period 1995-2017. The small differences in the profit share between the digital and the non-digital sector suggests that there is a competitive market structure with low entry barriers with limited possibilities to earn excessive profits. However, given the possibilities to move intangible capital internationally to tax havens, these figures could severely understate true rents earned in this sector.

Information about the endowment of the workforce with digital skills is contained in the EU Labour Force Survey, which suggests that in 2020 around 41\% of employed individuals in the digital sector are ICT specialists (including ICT Service managers, IC technology professionals, IC technicians as well as other unit groups that primarily involve the production of ICT services). We thus assume that the digital sector employs a higher share of workers with specialised digital skills $(40 \%)$ compared to the conventional production sector $(4 \%)$. We assume that the platform design sector only employs workers with digital skills. The remaining model parameters are standard. We assume a labour supply elasticity of 0.25 for both workers with and without digital skills. We set the employment rate to $60 \%$.

\section{Simulation results}

This section discusses how a COVID induced demand shift towards digital services affects the EU economy. As shown in the previous section the two sectors differ along various dimensions. The conventional production sector produces with a CRS production technology and low profit rates, while the digital sector produces subject to a sunk cost for the design, fixed costs associated with IT hardware and a small variable cost. The initial (software, intangible) investment in a design makes this sector more knowledge intensive, especially concerning persons with professional digital skills.

Platforms have a scale advantage. The extent in which this can be exploited for increasing profits depends on entry conditions in the digital sector. It is also likely that the flexibility in which labor supply (with and without advanced digital skills) responds to the shift in demand towards persons with advanced digital skills determines the extent in which the digital sector will actually grow in real terms and which (relative) price and wage effects will emerge. We present three scenarios. In the first scenario there is free entry in the digital sector. This is our theoretical baseline scenario corresponding to a fully competitive market structure where free entry eliminates all rents. In a second scenario we introduce entry barriers. This generates a positive profit rate consistent with observed rates in the data. In the third scenario we again assume free entry but lower labour supply elasticities in order to mimic an economy where the supply of skilled and unskilled labour adjusts more sluggishly to the qualification requirements of the digital sector. 

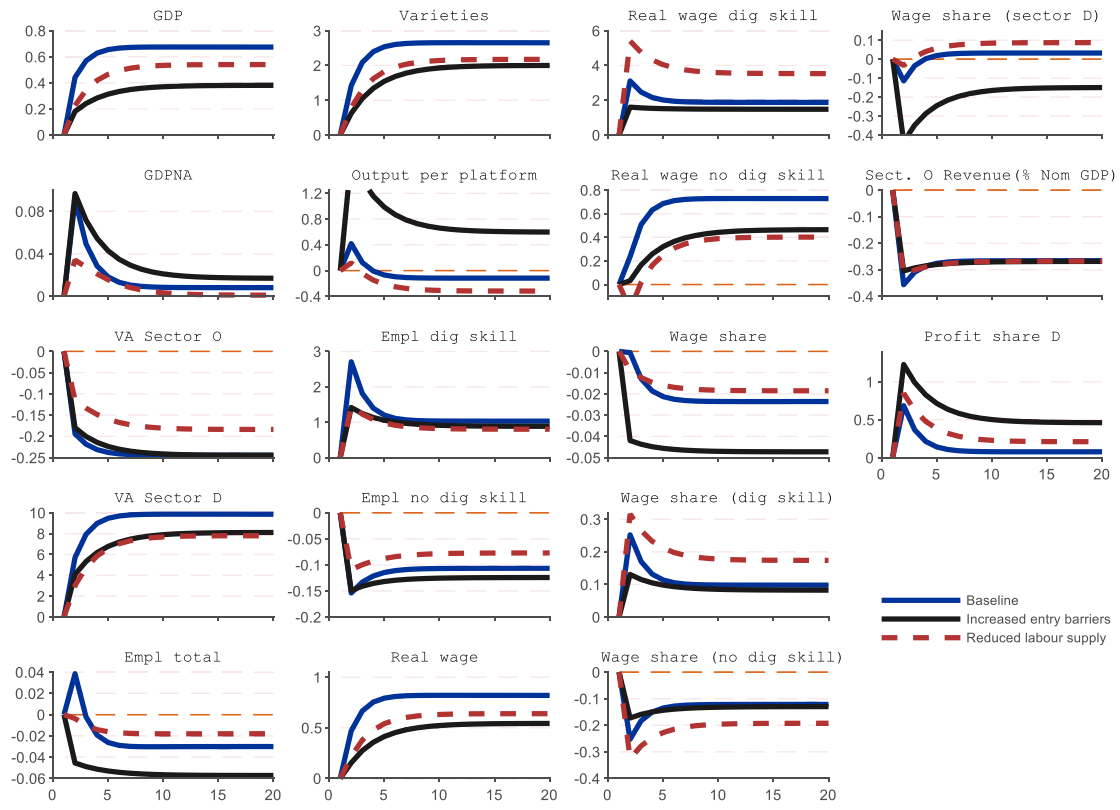

Fig. 10 Increased demand for digital services: Three scenarios

\subsection{Increased demand for digital services: Free entry scenario}

Figure 10 plots the impulse response functions of a number of aggregate variables following an exogenous shock in consumer preferences for all three scenarios. ${ }^{11} \mathrm{We}$ model the shift in demand towards the digital sector as a change in the share parameter $\left(\Delta \gamma_{t}<0\right)$ in the utility function of consumers, such that in the baseline simulation the share of the digital sector in the EU increases by about $10 \%$. In the baseline scenario we calibrate all parameters as outlined above but set the entry cost parameters to zero. That is, there are no rents generated in the digital sector in the baseline exercise. Because of CES preferences for digital services, there is a love for variety effect associated with the entry of new platforms. This effect is usually ignored in the measurement of sector value added and GDP. Therefore we report both a utility based definition of GDP (denoted as GDP) and a standard national accounts measure of GDP (GDPNA). ${ }^{12}$ We also provide the utility-based measure of value added in the digital sector jointly with its two components: the change in varieties and in output per platform.

Notes: The following variables are reported as percent deviation from their historical average (steady state): GDP, GDPNA, Value Added sector O, Value Added sector D, Employment, Varieties, Output per platform, Employment digital skills, Employment no digital skills, Real wage, Real wage digital skills, Real wage no digital skills.

\footnotetext{
11 The demand shock is retained throughout all scenarios.

12 Real GDP is measured at constant base year prices.
} 
The following variables are reported as percentage points deviation from their historical average (steady state): Wage share, Wage share digital skills, Wage share no digital skills, Wage share digital sector, Sector O revenue (\% of nominal GDP), Profit share.

The digital sector increases by about $10 \%$ (which includes the variety effect). The variety effect is relatively large because of the large mark up (the mark up equals the inverse of elasticity of substitution between varieties) and the conventional sector declines by less than $1 \%$ (there is no variety effect in the conventional sector). Apart from the absence of a variety effect, the fall of the conventional $(\mathrm{O})$ sector is mitigated by higher investment demand from the digital (D) sector and by a relative decline of wages for workers without digital skills.

Comparing the utility-based GDP measure with the national accounts measure reveals that the GDP gain is mostly a utility gain. There remains however a small positive GDPNA effect: Namely, average labour productivity in digital sector exceeds average labour productivity in the conventional sector. Effects on productivity are reflected by effects on output (GDP or GDPNA) as aggregate labour remains constant.

Real wages for workers with digital skills spike because of temporary high demand for digital experts as new platforms enter the market $(\mathrm{dA}>0)$ and require input from the design sector, which only employs workers with digital skills. The wage premium for digitally skilled workers rises with rising demand for digitally skilled workers.

The aggregate wage share is driven by two factors, the change in the wage share in the individual sectors and the composition effect reflecting the change in sector shares. Because of the functional form of the production technology and the assumption of constant mark ups in the conventional production sector, the wage share in the conventional production sector remains unchanged. The wage share in the digital sector increases because due to the wage increase of workers with digital skills. Because of the Leontief technology there is no possibility for digital platforms to substitute labour with capital. The aggregate wage share however declines slightly as a result of the change in composition towards a larger digital sector, which has a lower wage share.

The profit share increases. This largely reflects an increase in the price for platform designs because of a higher digital skill wage premium. In the following subsections we explore the consequences of deviating from labour supply and entry conditions.

\subsection{Increasing the entry barrier}

There are various arguments why entry into the digital sector may be more restricted. Network externalities may give an advantage to incumbent platforms. Financial frictions in Europe may make it difficult to generate funding for new platforms. Customers could be locked into specific digital ecosystems. In addition, due to the particularities of the IT business model (social media platforms can allow companies to infer information about users and non-users 
from shared data), companies can obtain personal data at below equilibrium prices, implying welfare inefficiencies for individuals (Acemoglu et al. 2019). Furthermore, some firms may become particularly efficient at reducing their marginal costs through intangible inputs, which discourages other firms from innovating. Such an IT shock may lead to rising national concentration and a decline of process improvements (Aghion et al. 2019; Ridder 2020). There is widespread concern among observers that large incumbent firms in digital markets act in a way such that, at best, they absorb innovation to shield themselves from potential competition and, at worst, acquire new market entrants to stymie or distort innovation, fortifying their dominant positions.

Though it appears that many digital services are dominated by large firms (Google, Facebook, Apple, Microsoft etc.), this does not necessarily imply that entry of new varieties into the digital sector is restricted, since large firms can add new varieties by taking over new start-ups or by offering new varieties as a result of their internal software design departments ${ }^{13}$ Though both narratives are plausible, it is interesting to explore what happens to the digital transition if entry is restricted. To simulate this, we set the entry cost parameter to a positive value such that entry declines by $25 \%$ relative to free entry.

Reduced entry slows down the speed of transition, in particular value added in the digital sector. Apart from reducing aggregate output effects, there are distributional effects. Reduced entry increases the profits of incumbent platforms because the marginal platform faces higher entry costs. With rising profits, the increase in the wage share in the digital sector reverses and declines, leading to a stronger decline of the aggregate wage share. Since there is still a substantial acceleration in the digital sector, the digital skill premium continues to increase (as well as the real wage of workers with digital skills).

\subsection{Reducing labour supply elasticities}

While the acquisition of digital skills is not explicitly modelled, we can draw some tentative insights from the variation of the labour supply elasticity. A labour supply elasticity equal to one is likely to represent a situation where the population can acquire professional digital skills relatively easily. Nevertheless, the demand shift towards digital services constitutes a labour market challenge since both sectors require workers with very different skills. With roughly equal skill requirements the labour supply elasticity would not constitute a specific problem. An increase of employment with digital skills requires education and training facilities and additional teaching staff. A scenario with a more inelastic labour supply can be interpreted as a situation where the duration and/ or cost of education and training slow down the digital transition governments

13 A recent example is that successful video conference systems have been offered by a new firm (ZOOM) as well as by a large incumbent firm (TEAMS by Microsoft). 
are less able to provide the necessary active labour market measures to accompany the digital transition. A lower labour supply elasticity reduces the expansion of the digital sector. In contrast to rising profits in the digital sector as we have seen in the previous scenario, limiting the supply of workers with professional digital skills increases the digital skill premium. This increases wages in the digital sector, and increases the wage share more strongly compared to the baseline scenario.

A comparison between the three scenarios highlights an important observation: The degree of labour supply and entry markets conditions in the economy determine to a large extent the distribution of economic rents between workers and capital owners. Another result which clearly comes out is the decline of the conventional production sector, which is accompanied by lower employment of persons without digital skills and a fall of their relative wage. Interestingly the real wage remains largely positive. This is mainly due to a variety effect in the ideal consumer price index.

Table 2 summarises the main outcomes of the different scenarios.

\section{Conclusion}

This paper attempts to provide a realistic calibration of a two-sector economy distinguishing a conventional and a digital sector, which has emerged in the late 90s but has remained at a GDP share below 10\%. COVID could give a permanent boost to the demand for existing digital services (e-commerce, streaming) and

Table 2 Comparing long run effects

\begin{tabular}{llll}
\hline & Baseline & $\begin{array}{l}\text { Entry Barriers } \\
(+25 \%)\end{array}$ & $\begin{array}{l}\text { Digital } \\
\text { Labor } \\
\text { Supply } \\
(-25 \%)\end{array}$ \\
\hline GDP & 0.7 & 0.4 & 0.5 \\
VA-O & -0.5 & -0.4 & -0.2 \\
VA-D & 11.0 & 9.0 & 7.5 \\
Variety & 4.0 & 3.0 & 3.0 \\
L Dig-Skills & 1.6 & 1.4 & 1.1 \\
L No Dig-Skills & -0.1 & -0.2 & -0.1 \\
WR & 0.8 & 0.5 & 0.6 \\
WR-Dig & 2.2 & 2.0 & 6.0 \\
WR-No-Dig & 0.6 & 0.4 & 0.1 \\
Wage Share & -0.03 & -0.05 & -0.01 \\
Wage Share (Dig-skills) & 0.2 & 0.14 & 0.3 \\
Wage Share (No-Dig-Skills) & -0.2 & -0.2 & -0.3 \\
Wage Share (Dig Sector) & 0.05 & -0.1 & 0.2 \\
Wage Share (O Sector) & -0.4 & -0.4 & -0.4 \\
Profit Share (Dig-Sector) & 0.1 & 0.6 & 0.3 \\
\hline
\end{tabular}


pave the way for the creation of new digital services (e.g. video conferencing, data analytics). The paper makes an attempt to characterise technological differences and market structures between the conventional and the digital sector and trace out the economic consequences of a persistent demand shift in favour of digital services. Free entry of new digital varieties and elastic supply of labour with digital skills, i. e. a rapid adjustment of the labour force to the new technological environment, allow for a smooth transition. However, a more sluggish adaptation of the labour force or barriers to the entry of new firms could make the process more difficult. The paper also shows how the distribution of economic rents between workers with digital skills and digital platforms are determined by labour supply conditions and entry barriers. This suggests that there is a role for competition policy as well as education and training and labour market policies to support the digital transition.

The framework presented in this paper can be extended in various directions. An immediate extension would be to also consider digital services that can be used by conventional firms and would increase their productivity. It must also be emphasised that the distinction between a conventional and a digital sector will become more and more difficult since the conventional sector will itself become more digital. The role of education for the supply conditions of digital skills could also be examined further. Another interesting aspect is the international dimension. In this paper, digital services are provided by domestic firms, while in the EU case a significant fraction of these services will probably be imported. This also has repercussions for the structure of international trade and the current account, which are neglected in this paper. On the policy side, we have concentrated on labour market and competition policies but have neglected tax policies. In this area, the IMF (2020) recommended that governments could consider raising progressive taxes on more affluent individuals, and suggested taxing high income brackets, high-end property, capital gains, and wealth. Various factors, such as whether the superrich are rent-seekers and/or job creators and the tax elasticity of the tax bases used for taxation of the superrich, would need to be analysed further for the design of such policies (see for instance Scheuer and Slemrod 2020). Our framework could be extended to analyse these issues as well. 


\section{Annex 1}

Definition of the digital sector (NACE sectors)

\begin{tabular}{ll}
\hline $\mathbf{J}$ & Information and Communication \\
\hline 58 & Publishing activities \\
59 & $\begin{array}{c}\text { Motion picture, video and television programme production, sound recording } \\
\text { and music publishing activities } \\
\end{array}$ \\
60 & Programming and broadcasting activities \\
61 & Telecommunications \\
62 & Computer programming, consultancy and related activities \\
63 & Information service activities \\
G47 & Retail trade except motor vehicles and motorcycles \\
47.91 & Retail sale via mail order houses or via Internet (included in "broad" definition) \\
\hline
\end{tabular}

Definition of the digital sector according to Benages et al. (2020):

\section{b) ICT sector (operational definition)}

\begin{tabular}{|c|c|}
\hline $261-264,582,61,62,631,951$ & $\mathrm{~A}^{\prime}$. ICT Total (operational) $\left[\mathrm{A}^{\prime}=\mathrm{B}^{\prime}+\mathrm{C}\right]$ \\
\hline $261-264$ & $\mathrm{~B}^{\prime}$. ICT manufacturing industries (operational) $\left[\mathrm{B}^{\prime}=1\right.$ to 4$]$ \\
\hline 261 & [1] Manufacture of electronic components and boards \\
\hline 262 & [2] Manufacture of computers and peripheral equipment \\
\hline 263 & [3] Manufacture of communication equipment \\
\hline 264 & [4] Manufacture of consumer electronics \\
\hline $582,61,62,631,951$ & C. ICT services industries (operational) $[\mathrm{C}=8+9]$ \\
\hline 61 & [8] Telecommunications \\
\hline $582,62,631,951$ & [9] Computer and related activities $[9=10+11+12+13]$ \\
\hline \multicolumn{2}{|l|}{ c) $M C$ sector } \\
\hline $581,59,60,639$ & E. $\mathrm{MC}$ sector $[\mathrm{E}=\mathrm{F}+\mathrm{G}+\mathrm{H}]$ \\
\hline 581 & $\begin{array}{l}\text { F. Publishing of books, periodicals and other publishing activities } \\
{[\mathrm{F}=14 \text { to } 16]}\end{array}$ \\
\hline $5811-5812$ & [14] Book publishing; Publishing of directories and mailing lists \\
\hline 5811 & [14.1] Book publishing \\
\hline 5812 & [14.2] Publishing of directories and mailing lists \\
\hline $5813-5814$ & [15] Publishing of newspapers, journals and periodicals \\
\hline 5813 & [15.1] Publishing of newspapers \\
\hline 5814 & [15.2] Publishing of journals and periodicals \\
\hline 5819 & [16] Other publishing activities \\
\hline $59-60$ & G. Audiovisual and broadcasting activities $[\mathrm{G}=17+18]$ \\
\hline 59 & $\begin{array}{l}\text { [17] Motion picture, video and television programme production, sound } \\
\text { recording and music publishing activities }\end{array}$ \\
\hline 591 & [17.1] Motion picture, video and television programme activities \\
\hline 5911 & $\begin{array}{l}\text { [17.1.1] Motion picture, video and television programme production } \\
\text { activities }\end{array}$ \\
\hline
\end{tabular}




\section{b) ICT sector (operational definition)}

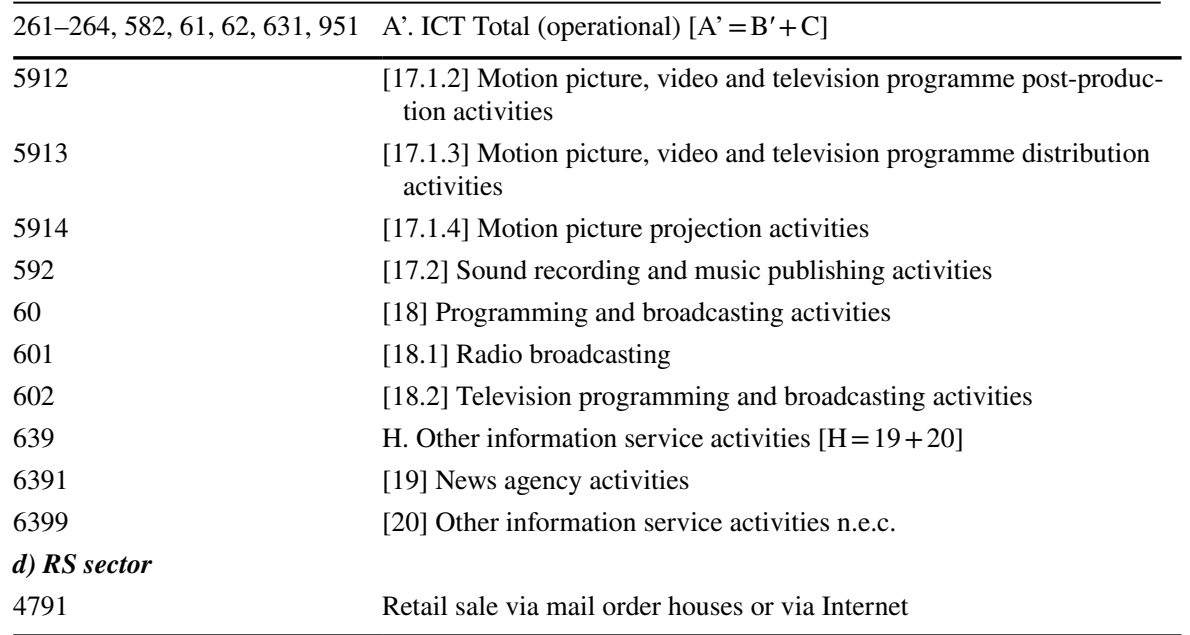

\section{Annex 2}

Assumptions underpinning the simulated ICT demand shock

\section{Simulation assumptions - direct effects}

\begin{tabular}{|c|c|c|c|}
\hline Sector / channel & mechanism & Impact & explanation \\
\hline Overall digital sectors & $\begin{array}{l}\text { Faster adoption of } \\
\text { digital solutions (other } \\
\text { than those detailed } \\
\text { below) due to adapta- } \\
\text { tion, disruption, and } \\
\text { creative destruction }\end{array}$ & $\begin{array}{l}10-15 \% \text { increase in } \\
\text { demand }\end{array}$ & $\begin{array}{l}\text { Reports (e.g. McKinsey } \\
\text { 2020b) about jump in } \\
\text { IT adoption in an order } \\
\text { of several years of pre- } \\
\text { crisis annual growth. } \\
\text { This also includes the } \\
\text { impact of telework and } \\
\text { e-commerce on demand } \\
\text { for digital equipment } \\
\text { and services explained } \\
\text { below. }\end{array}$ \\
\hline Of which: e-commerce & $\begin{array}{l}\text { Move of retail activity } \\
\text { from physical shops to } \\
\text { e-commerce. } \\
\text { Increased demand for } \\
\text { digital services } \\
\text { Indirect effect: Reduced } \\
\text { demand for commer- } \\
\text { cial space }\end{array}$ & $\begin{array}{c}20 \% \text { increase in } \\
e \text {-commerces }\end{array}$ & $\begin{array}{l}\text { E-commerce boosted } \\
\text { by about } 40 \% \text { during } \\
\text { lockdowns. Take half } \\
\text { as starting point for } \\
\text { permanent effect }\end{array}$ \\
\hline
\end{tabular}




\begin{tabular}{|c|c|c|c|}
\hline Sector / channel & mechanism & Impact & explanation \\
\hline $\begin{array}{l}\text { N.B.: Retail trade: price } \\
\text { impact }\end{array}$ & $\begin{array}{l}\text { Move towards e-com- } \\
\text { merce reduces cost of } \\
\text { shops, }\end{array}$ & $\begin{array}{l}0.5 \mathrm{pp} \text {. lower NEIG } \\
\text { inflation due to cost- } \\
\text { savings }\end{array}$ & $\begin{array}{l}\text { Assume lasting increase } \\
\text { of B2C e-commerce by } \\
20 \% \text {. Inflation impact } \\
\text { according to Mohr and } \\
\text { Rubene. }\end{array}$ \\
\hline $\begin{array}{l}\text { Of which: Working from } \\
\text { home }\end{array}$ & $\begin{array}{l}\text { Increased demand for } \\
\text { digital equipment and } \\
\text { digital services } \\
\text { Indirect effect: reduced } \\
\text { demand for office } \\
\text { space }\end{array}$ & $\begin{array}{l}\text { 15\% increase of } \\
\text { demand for digital } \\
\text { services (videoconfer- } \\
\text { encing and com- } \\
\text { munications, remote } \\
\text { customer service, } \\
\text { data storage, ...); } \\
\text { somewhat lower for } \\
\text { office equipment (only } \\
\text { partial duplication } \\
\text { between home and } \\
\text { office) }\end{array}$ & $\begin{array}{l}30 \% \text { of workers regularly } \\
\text { work from home } \\
2-3 \text { days per week, i.e. } \\
15 \% \text { each day. }\end{array}$ \\
\hline
\end{tabular}

\section{Possible indirect effects not considered in our model simulations.}

\begin{tabular}{|c|c|c|c|}
\hline Sector / channel & mechanism & Impact & explanation \\
\hline $\begin{array}{l}\text { Commercial property } \\
\text { / non-residential } \\
\text { construction }\end{array}$ & $\begin{array}{l}\text { Less demand for office } \\
\text { space due to telework } \\
\text { Less demand for } \\
\text { physical shops due to } \\
\text { e-commerce } \\
\text { Less construction of } \\
\text { shops and offices }\end{array}$ & $\begin{array}{l}\text { Drop of office space } \\
\text { demand by } 8 \% \\
\text { Drop of shop surface } \\
\text { demand by } 10 \% \\
\text { Impact on construction } \\
\text { sector activity } 8 \%\end{array}$ & $\begin{array}{l}\text { Assume as above that } \\
15 \% \text { of office workers } \\
\text { telework on any given } \\
\text { day. Assume the related } \\
\text { consolidation of office } \\
\text { space is one-half of } \\
\text { that. } \\
\text { Assume consolidation of } \\
\text { commercial space by } \\
\text { half of drop in turnover } \\
\text { To reduce the stock } \\
\text { of non-residential } \\
\text { buildings by } 10 \% \text { over } \\
10 \text { years, new construc- } \\
\text { tion would have to drop } \\
\text { by } 25 \% \text { (assuming a } \\
\text { depreciation rate of } \\
5 \% 14 \text { ). As non-residen- } \\
\text { tial building represents } \\
32 \% \text { of construction, } \\
\text { the impact on the sector } \\
\text { as a whole would be } \\
\text { around } 8 \% \text {. }\end{array}$ \\
\hline
\end{tabular}

\footnotetext{
14 This is a high depreciation rate. But note that with a lower depreciation rate, construction would even have to drop more to allow the transition towards a lower stock of non-residential property.
} 


\begin{tabular}{|c|c|c|c|}
\hline Sector / channel & mechanism & Impact & explanation \\
\hline Transport services & $\begin{array}{l}\text { Less business travel, } \\
\text { less commuting }\end{array}$ & $\begin{array}{l}3 \% \text { drop of passenger } \\
\text { transport by air } \\
4 \% \text { drop of passenger } \\
\text { transport by rail. }\end{array}$ & $\begin{array}{l}\text { Business travel demand } \\
\text { by air could decline by } \\
25 \% \text { (ad-hoc assump- } \\
\text { tion). Corporate travel- } \\
\text { lers represent } 12 \% \text { of air } \\
\text { passenger transport. }\end{array}$ \\
\hline Agglomeration effects & $\begin{array}{c}\text { Lower TFP growth due } \\
\text { to dis-agglomeration } \\
\text { related to telework }\end{array}$ & $\begin{array}{l}\text { TFP growth drops by up } \\
\text { to }-0.1 \mathrm{pp}\end{array}$ & $\begin{array}{l}\text { Combes and Gobil- } \\
\text { lon (2014): Elasticity } \\
\text { of productivity with } \\
\text { respect to density in } \\
\text { Europe in a range of } \\
0.05-0.13 \text {. Assume } \\
\text { decrease of density } \\
\text { by } 5 \%\end{array}$ \\
\hline
\end{tabular}

\section{References}

Accenture (2020). Is it time for a course correction? COVID-19: what to do now, What to do Next. https://www.accenture.com/us-en/about/company/coronavirus-course-correction-enterprise-recov ery

Acemoglu, D, Restrepo P (2017) Robots and jobs: Evidence from US labor markets NBER working Paper No. 23285. https://doi.org/10.3386/w23285

Acemoglu D, Makhdoumi A, Malekian A, Ozdaglar A (2019) Too much data: prices and inefficiencies in data markets. NBER Working Paper No. 26296. https://doi.org/10.3386/w26296

Aghion P, Bergeaud A, Boppart T, Klenow PJ, Li H (2019) A theory of falling growth and rising rents. NBER Working Paper 26448. https://doi.org/10.3386/w26448

Akerman A, Gaarder I, Mogstad M (2015), The skill complementarity of broadband internet NBER Working Paper 20826. https://doi.org/10.3386/w20826

Almeida V, Barrios S, Christl M, De Poli S, Tumino A, van der Wielen W (2020) Households' income and the cushioning effect of fiscal policy measures during the Great Lockdown. JRC Working Papers on Taxation and Structural Reforms No 06/2020

Anderton R, Jarvis V, Labhard V, Morgan J, Petroulakis F, Vivian L (2020) Virtually everywhere? Digitalisation and the euro area and EU economies: Degree, effects, and key issues. ECB Occasional paper 244 revised December 2020. https://doi.org/10.2866/339471

Andrews D, Nicoletti G, Timiliotis C (2018) Digital technology diffusion: a matter of capabilities, incentives or both? OECD Economics Department Working Paper 1476. https://doi.org/10.1787/7c542 c16-en

Autor DH (2013) The task approach to labor markets: an overview. J Labour Market Res 46(3):185-199. https://doi.org/10.3386/w18711

Autor DH (2015) Why are there still so many jobs? The history and future of workplace automation. J Econ Perspect. Summer 29(3): 3-30 https://doi.org/10.1257/jep.29.3.3

Autor D, Salomons A (2018) Is automation labor share-displacing? Productivity growth, employment, and the labor share. Brook Pap Econ Act 49(1):1-87. https://doi.org/10.3386/w24871

Autor D, Dorn D, Katz L, Patterson C, van Reenen J (2017) Concentrating on the fall of the labour share. Am Econ Rev 107(5):180-185. https://doi.org/10.3386/w23108

Autor D, Dorn D, Katz LF, Patterson C, van Reenen, J (2020) The fall of the labor share and the rise of superstar firms. Quart J Econ, pp 645-709. https://doi.org/10.3386/w23396

Balsmeier B, Woerter M (2019) Is this time different? How digitalization influences job creation and destruction. Res Policy 48(8):103765. https://doi.org/10.1016/j.respol.2019.03.010

Barrero JM, Bloom N, Davis SJ (2021) Why Working from home will stick. https://doi.org/10.3386/ w28731 
Benages E, Hernández L, Mínguez C, Pascual F, Robledo JC, Rosell I, Salamanca J, Solaz M, Cardona M, López-Cobo M, Righi R, Samoili S, Vazquez-Prada Baillet M (2020) The 2020 PREDICT dataset methodology. European Commission - Joint Research Center Technical Report

Bengtsson E, Waldenström D (2018) Capital Shares and Income Inequality: Evidence from the Long Run. J Econ Hist 78(3):712-743. https://doi.org/10.1017/S0022050718000347

Berlingieri G, Calligaris S, Criscuolo C, Verlhac R (2020) Last but not least: laggard firms, technology diffusion and its structural and policy determinants. OECD Science Technology and Industry Policy Paper 86. https://doi.org/10.1787/281bd7a9-en

Berman E, Bound J, Machin S (1998) Implications of skill-biased technological change: international evidence. Q J Econ 113(4):1245-1279. https://doi.org/10.3386/w6166

Berry S, Gaynor M, Morton FS (2019) Do increasing markups matter? Lessons from Empirical Industrial Organization. J Econ Perspect 33(3):44-68. https://doi.org/10.3386/w26007

Bessen J (2017) Information technology and industry concentration. Boston University School of Law, Law and Economics Research Paper, pp 17-41. https://doi.org/10.1086/708936

Biagi F, Falk M (2017) The impact of ICT and e-commerce on employment in Europe. J Policy Model 31:1-18. https://doi.org/10.1016/j.jpolmod.2016.12.004

Bloom N, Jones CI, van Reenen J, Webb M (2020) Are ideas getting harder to find? Am Econ Rev 110(4):1104-1144. https://doi.org/10.3386/w23782

Borko S, Geerts W, Wang H (2020) The travel industry turned upside down: insights, analysis and action for travel executives. Skift Research Report

Brunow S, Blien U (2015) Agglomeration effects on labor productivity: An assessment with microdata, REGION, European Regional Science Association 2, pp. 33-53

Brynjolfsson E, Rock D, Syverson C (2019) Artificial intelligence and the modern productivity paradox: A clash of expectations and statistics in Agrawal A, Gans J, Goldfarb A (eds) The Economics of Artificial Intelligence: An Agenda. Chicago: University of Chicago Press, pp. 23-57. https://doi.org/ 10.3386/w24001

Calligaris S, Criscuolo C, Marcolin L (2018) mark-ups in the digital era, OECD science, Technology and Industry Working Papers 2018/10. https://doi.org/10.1787/4efe2d25-en

Cardona M, Kretschmer T, Strobel T (2013) ICT and productivity: conclusions from the empirical literature. Inf Econ Policy 25:109-125. https://doi.org/10.1016/j.infoecopol.2012.12.002

Cardona M, Duch-Brown N, Francois J, Martens B, Fan Y (2015) The macro-economic impact of e-Commerce in the EU Digital Single Market. JRC Technical Reports, Institute for Prospective Technological Studies Digital Economy Working Paper 2015/09 https://doi.org/10.2139/ssrn.25358 42

Chava S, Oettl A, Singh M, Zeng L (2018) The dark side of technological Progress? Impact of E-Commerce on Employees at Brick-and-Mortar

Claeys G, Demertzis M (2021) The productivity paradox: policy lessons from MICROPROD Bruegel, Policy Contribution Issue $\mathrm{n}^{\circ} 01 / 21$

Combes PP, Gobillon L, (2014) The empirics of agglomeration economies, IZA Discussion Paper No. 8508. https://doi.org/10.1016/B978-0-444-59517-1.00005-2

Consolo (2020) A general equilibrium perspective of how automation affects the labour market

Croitorov O, Filippeschi G, Licchetta M, Pfeiffer P, Reut A, Simons W, Thum-Thysen A, Vandeplas A, Vogel L (2021) The macroeconomic impact of the COVID-19 pandemic in the euro area. Q Rep Euro Area 20(2):7-16

D'Adamo G, Bianchi M, Granelli L (2021) Digitalization and beyond: the Covid-19 pandemic and productivity growth in G20 countries. ECFIN Economic Brief, forthcoming

David A (1985) Clio and the economics of QWERTY. Am Econ Rev 75(2):332-337

De Loecker J, Eeckhout J, Unger G (2020) The rise of market power and the macroeconomic implications. Quart J Econ 135(2):561-644. https://doi.org/10.3386/w23687

Decker R, Haltiwanger J, Jarmin R, Miranda J (2014) The role of entrepreneurship in US job Creation and Economic Dynamism. J Econ Perspect 28(3):3-24. https://doi.org/10.1257/jep.28.3.3

Deming DJ, Noray K (2018) STEM careers and the changing skills requirements of work NBER Working Paper No. 25065. https://doi.org/10.3386/w25065

Dhar V, Sundararajan A (2007) Issues and opinions-information technologies in Business: A Blueprint for Education and Research. Inform Syst Res, 18(2), 125-141. https://doi.org/10.1287/isre.1070. 0126 
Dierx A, Ilzkovitz F, Pataracchia B, Ratto M, Thum-Thysen A, Varga J (2017) Does EU competition policy support inclusive growth? J Compet Law Econ 13(2), 225-260. https://doi.org/10.1093/joclec/nhx015

European Commission Directorate-General of Communications Networks, Content and Technology (2020). Shaping the digital transformation in Europe. Final report, Brussels https://doi.org/10.2759/ 294260

European Investment Bank (2021) Investment report 2020/2021: Building a smart and green Europe in the COVID-19 era. Luxemburg. https://doi.org/10.2867/904099

Falk M, Hagsten E (2015) E-commerce trends and impacts across Europe. UNCTAD Discussion Paper 220. https://doi.org/10.1016/j.ijpe.2015.10.003

Fitzpatrick M, Gill I, Libarikian A, Smaje K, Zemmel R (2020) The digital-led recovery from COVID19: Five questions for CEOs. McKinsey Digital https://www.mckinsey.com/business-functions/ mckinsey-digital/our-insights/the-digital-led-recovery-from-covid-19-five-questions-for-ceos

Fletcher G, Griffiths M (2020) Digital transformation during a lockdown. Int J Inform Manag 55, 102185. https://doi.org/10.1016/j.ijinfomgt.2020.102185

Furceri D, Celik SK, Tovar Jalles J, Koloskova K (2021) Recessions and total factor productivity: Evidence from sectoral data. Econ Modell 94, pp 130-138 https://doi.org/10.1016/j.econmod.2020.09. 025

Francese M, Mulas-Granados C (2015) Functional Income Distribution and Its Role in Explaining Inequality. IMF Working Paper 15/244

Gordon, RJ (2016) The rise and fall of American growth, Princeton University Press 10.1257/aer. p20161126

Gornig M, Schiersch A (2019) Agglomeration economies and the firm TFP: Different effects across industries. DIW Berlin Discussion Paper No. 1788 https://doi.org/10.2139/ssrn.3339204

Grossman GM, Helpman E (1992a) Innovation and growth in the global economy. The MIT Press, Cambridge, Mass

Grossman GM, Helpman E (1992b) Innovation and growth in the global economy. The MIT Press, Cambridge, Mass. https://doi.org/10.1111/j.1467-9485.1993.tb00652.x

Grundke R, Jamet S, Kalamova M, Keslair F, Squicciarini M (2017) Skills and global value chains. OECD Science, Technology and Industry Working Papers, 2017/06/23 https://doi.org/10.1787/ cdb5de9b-en

Grundke R, Marcolin L, Nguyen TLB, Squicciarini M (2018) Which skills for the digital era? Returns to skills analysis. OECD Science, Technology and Industry Working Papers 2018/09 https://doi.org/ 10.1787/9a9479b5-en

Gutierrez G, Philippon T (2020) Some facts about dominant firms. NBER Working Paper No. 109 https:// doi.org/10.3386/w27985

Hall R, Jorgenson D (1967) Tax policy and investment behaviour. Am Econ Rev 57(3):391-414

International Monetary Fund (2020) World economic outlook. IMF publishing

Koellinger P (2008) The relationship between technology, innovation, and firm performance-Empirical evidence from-business in Europe. Res Pol, 37(8), pp 1317-1328 https://doi.org/10.1016/j.respol. 2008.04.024

Konings J, Roodhooft F (2002) The effect of e-business on corporate performance: firm-level evidence from Belgium. De Economist 150(5)

Korinek and $\mathrm{Ng}$ (2017) Superstar Firms (mimeo)

Liu TK, Chen RJ, Huang CCJ, Yang CH (2013) E-commerce, R\&D, and productivity: Firm level evidence from Taiwan. Inform Econ Pol 25, 272-283 https://doi.org/10.1016/j.infoecopol.2013.07.001

Mattana E, Smeets V, Warzynski F (2020) Changing skill structure and COVID-19, COVID vetted and real-time papers. Issue 45, 28 August 2020, CEPR Press

McKinsey (2020a) How COVID-19 has pushed companies over the technology tipping point—and transformed business forever. https://www.mckinsey.com/business-functions/strategy-and-corporatefinance/our-insights/how-covid-19-has-pushed-companies-over-the-technology-tipping-point-andtransformed-business-forever

McKinsey (2020b) Rebooting retail: How technology will shape the future of retail. https://www.mckin sey.com/ /media/mckinsey/industries/retail/our\%20insights/rebooting\%20retail\%20how\%20tec hnology $\% 20$ will $\% 20$ shape $\% 20$ the $\% 20$ future $\% 20$ of $\% 20$ retail/rebooting-retail-how-technology-willshape-the-future-of-retail.pdf

Michaels G, Natraj A, van Reenen J (2014) Has ICT polarized skill demand? Evidence from eleven countries over 25 years. Rev Econ Statist 96 (1), 60-77. https://doi.org/10.1162/REST_a_00366 
Mohr M, Rubene I (2017) Econometric evidence for the effect of e-commerce on non-energy industrial goods inflation. In: Ciccarelli M, Osbat C (eds.): Low inflation in the euro area: Causes and consequences, ECB Occasional Paper 181. https://doi.org/10.2866/503793

Morandini M, Thum-Thysen A, Vandeplas A (2020) Facing the digital transformation: are digital skills enough? No 054, European Economy - Economic Briefs. Directorate General. Economic and Financial Affairs (DG ECFIN), European Commission. https://doi.org/10.2765/846577

Nagel L (2020) The influence of the COVID-19 pandemic on the digital transformation of work. Int J Soc Soc Pol 40(9/10):861-875. https://doi.org/10.1108/IJSSP-07-2020-0323

Nalbach E, Roeger W (2018) Growth with a digital sector, labor productivity and the digital economy. Second joint IZA/OECD workshop held in Paris.

OECD (1999) Economic and Social Impact of E-commerce: Preliminary Findings and Research Agenda. OECD Digital Economy Papers 40, OECD Publishing, Paris. https://doi.org/10.1787/2365885263 34

OECD (2019) Unpacking E-Commerce: Business Models, Trends and Policies. OECD Publishing, Paris. https://doi.org/10.1787/23561431-en

OECD (2020) E-commerce in the times of COVID-19. OECD Publishing, Paris. https://doi.org/10.1787/ 3a2b78e8-en

Palomino J, Rodríguez J, Sebastian R (2020) Wage inequality and poverty effects of lockdown and social distancing in Europe. Eur Econ Rev 129. https://doi.org/10.1016/j.euroecorev.2020.103564

Piketty T (2014) Capital in the twenty-first century. Harvard University Press.

Priyono A, Moin A, Oktaviani Putri VNA (2020) Identifying digital transformation paths in the business model of SMEs during the COVID-19 pandemic. J Open Innovation: Technology, Market, and Complexity 6:104. https://doi.org/10.3390/joitmc6040104

Quiroz Romero C, Rodríguez Rodríguez D (2009) E-commerce and efficiency at the firm level. Int J Prod Econ 126:299-305. https://doi.org/10.1016/j.ijpe.2010.04.004

Rapaccini M, Saccani N, Kowalkowski C, Paiola M, Adrodegari F (2020) Navigating disruptive crises through service-led growth: The impact of COVID-19 on Italian manufacturing firms. Industr Market Manag 88:225-237. https://doi.org/10.1016/j.indmarman.2020.05.017

Ridder MD (2020) Market power and innovation in the intangible economy. Working Paper.

Rifkin J (2014) Zero marginal cost society. Palgrave Macmillan New York, NY

Riom C, Valero Z (2020) The business response to Covid-19: the CEP-CBI survey on technology adoption. Centre for Economic Performance COVID-19 Analysis, paper ${ }^{\circ} 9$

Roeger W (2019) Digital technical progress, aggregate growth and the wage share. Mimeo.

Romer PM (1990) Endogenous technological change. J Pol Econ 98:71-102

Rückert D, Veugelers R, Weiss C (2020) The growing digital divide in Europe and the United States. EIB Working Paper 2020/07. 10.2867/222528

Scheuer F, Slemrod J (2020) Taxation and the superrich. Annual Review of Economics 12:189-211. https://doi.org/10.3386/w26207

Sostero M, Milasi S, Hurley J, Fernandez-Macías E, Bisello M (2020) Teleworkability and the COVID19 crisis: a new digital divide? JRC Working Papers Series on Labour, Education and Technology.

Stolper, W. and P. Samuelson Source (1941 Protection and real wages. Rev Econ Stud, 9(1), 58-73. https://www.jstor.org/stable/2967638

Sundararajan A (2016) The sharing economy: the end of employment and the rise of crowd-. Based Capitalism. The MIT Press, Cambridge, MA. https://doi.org/10.1177/0972262917712390

Terzi N (2011) The impact of e-commerce on international trade and employment. Procedia Social and Behavioral Sciences 24:745-753. https://doi.org/10.1016/j.sbspro.2011.09.010

United Nations Economic Commission for Latin America and the Caribbean (2002) Electronic Commerce, International Trade and Employment: Review of The Issues. UN, Economic. Commission for Latin America and the Caribbean ECLAS, Washington.

van Ark B, de Vries K, Erumban A (2019) Productivity \& innovation competencies in the midst of the digital transformation age: A EU-US comparison. European Economy Fellowship Initiative 20182019, Discussion Paper 119. 10.2765/106835

van Ark B, de Vries K, Erumban A (2021) How not to miss a productivity revival once again. Natl Inst Econ Rev 255(1):9-24. https://doi.org/10.1017/nie.2020.49

Waldfogel J (2015) Digitization and the quality of new media products: the case of music chap. 14 in Economic Analysis of the Digital Economy, edited by Goldfarb A, Greenstein SM, Tucker CE. pp. 407-42. Chicago: University of Chicago Press. https://doi.org/10.7208/chicago/9780226206981. 003.0014 . 
Weghake J, Grabicki F (2016) Why the QWERTY-phenomenon is not just "in the minds of theorists" and why it could nonetheless be no problem in reality, TUC Working Papers in Economics, No. 17, Technische Universität Clausthal, Abteilung für Volkswirtschaftslehre, Clausthal-Zellerfeld. https:// doi.org/10.21268/20161213-164250

Publisher's note Springer N+ature remains neutral with regard to jurisdictional claims in published maps and institutional affiliations. 